\title{
Neuromodulation of the Feedforward Dentate Gyrus-CA3 Microcircuit
}

\author{
Luke Y. Prince *, Travis J. Bacon, Cezar M. Tigaret and Jack R. Mellor * \\ Centre for Synaptic Plasticity, School of Physiology, Pharmacology and Neuroscience, University of Bristol, Bristol, UK
}

The feedforward dentate gyrus-CA3 microcircuit in the hippocampus is thought to activate ensembles of CA3 pyramidal cells and interneurons to encode and retrieve episodic memories. The creation of these CA3 ensembles depends on neuromodulatory input and synaptic plasticity within this microcircuit. Here we review the mechanisms by which the neuromodulators aceylcholine, noradrenaline, dopamine, and serotonin reconfigure this microcircuit and thereby infer the net effect of these modulators on the processes of episodic memory encoding and retrieval.

Keywords: acetylcholine, noradrenaline, dopamine, serotonin, mossy fiber, dentate gyrus, CA3, computational modeling

\section{INTRODUCTION}

OPEN ACCESS

Edited by:

Sukumar Vijayaraghavan, University of Colorado Denver School

of Medicine, USA

Reviewed by:

Eric Hanse

University of Gothenburg, Sweden Laura Lee Colgin,

University of Texas at Austin, USA

*Correspondence:

Luke Y. Prince

l.y.prince@bristol.ac.uk

Jack R. Mellor

jack.mellor@bristol.ac.uk

Received: 31 July 2016 Accepted: 20 September 2016 Published: 17 October 2016

Citation:

Prince LY, Bacon TJ, Tigaret CM and Mellor JR (2016) Neuromodulation of the Feedforward Dentate Gyrus-CA3

Microcircuit.

Front. Synaptic Neurosci. 8:32. doi: 10.3389/fnsyn.2016.00032
The hippocampus has been strongly implicated in encoding and retrieval of memories since the early work of Scoville and Milner several decades ago (Scoville and Milner, 1957; Squire, 1992), but the mechanisms through which this is achieved remain largely elusive. The hippocampal circuit receives input from the entorhinal cortex and transforms this information through successive synaptic transmission in feedforward and recurrent networks before projecting back to the entorhinal cortex. Theoretical investigations have shown that this transformation through a succession of feedforward and recurrent networks is well suited to the encoding and retrieval of memories in neural structures (Marr, 1971; McNaughton and Morris, 1987; Treves and Rolls, 1994; Lengyel et al., 2005).

The dentate gyrus and CA3 subfields are central to these processes. Dentate gyrus granule cells project to recurrently connected CA3 pyramidal cells and this microcircuit (Figure 1) has been shown to contribute to learning contexts (McHugh et al., 2007; Kheirbek et al., 2013) and detecting novelty (Hunsaker et al., 2007, 2008), which are key requirements for episodic and recognition memory. However, encoding and retrieval engage distinct processes as demonstrated by evidence that contralateral lesions to dentate gyrus and CA3 impaired encoding, but not retrieval in a spatial maze learning task relative to ipsilateral lesioned and unlesioned animals (Jerman et al., 2006) whilst damage to direct entorhinal-CA3 inputs impairs retrieval but not encoding (Lee and Kesner, 2004). These and other data support a long held hypothesis of a double dissociation in encoding and retrieval pathways to CA3 (Treves and Rolls, 1994).

Episodic memories are thought to be encoded in CA3 by the distribution of synaptic efficacies derived through activation of long-term synaptic plasticity mechanisms by correlated spiking (Hebb, 1949; Mishra et al., 2016). These distributions of synaptic weights form sparse orthogonalized cell assemblies that are reactivated during memory retrieval with high precision even with partial or corrupted cues (O'Reilly and McClelland, 1994), and retain sufficient flexibility to allow memory sequences to be retrieved when required (Lisman, 1999). Together, encoding and retrieval is supported by the processes of pattern separation and completion, where separation 


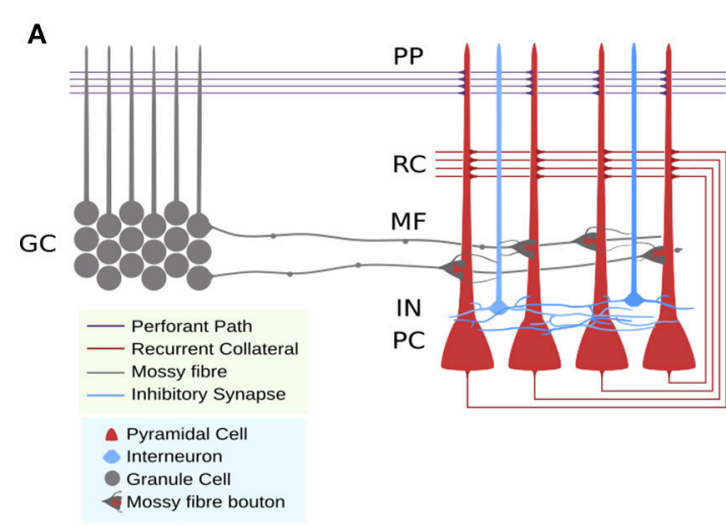

B

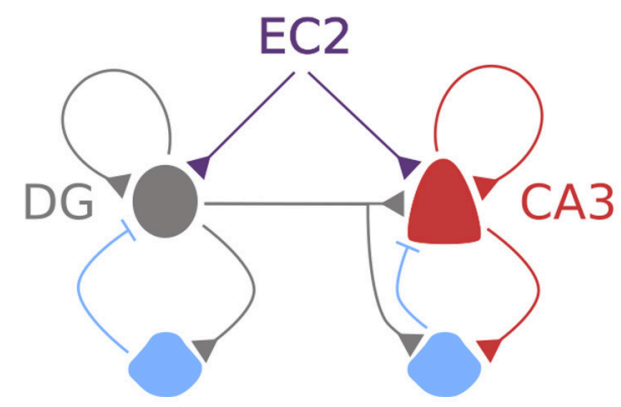

FIGURE 1 | Circuit schemas for DG-CA3 microcicuit. (A) Detailed schematic showing approximate locations of synaptic connections to CA3 pyramidal cells and differences in axon terminals. (B) Simplified schematic showing feedforward and recurrent circuits with feedforward and feedback inhibition.

refers to a decrease in output correlation relative to the input and supports optimal encoding, and completion refers to an increase in output correlation relative to the input and supports precise retrieval (O'Reilly and McClelland, 1994; Fuhs and Touretzky, 2000; Nolan et al., 2011). Although theories have often posited that the dentate gyrus performs pattern separation and CA3 performs pattern completion (O'Reilly and McClelland, 1994), more recent experimental evidence suggests that both subfields can perform both functions (Leutgeb et al., 2007).

An important and often ignored component of memory encoding and retrieval is the neuromodulatory influence of acetylcholine (ACh), dopamine (DA), noradrenaline (NA), and serotonin (5-HT). Each of these neuromodulators are released in the hippocampus and have been suggested to encode information pertaining to reward, novelty, salience, and surprise, all of which are relevant for optimizing processes involved in encoding and retrieval of information when traversing an uncertain environment with limited computational resources. To date there have been few theoretical efforts to integrate the actions of neuromodulators in memory encoding and retrieval. In this article, we propose potential mechanisms through which encoding and retrieval can be modulated by considering observed and putative effects on cellular and synaptic properties throughout the DG-CA3 microcircuit.

\section{CIRCUIT MECHANISMS FOR MEMORY ENCODING AND RETRIEVAL IN THE CA3 REGION OF THE HIPPOCAMPUS}

\subsection{Dentate Gyrus Output and Function}

The dentate gyrus (DG) consists of a large population $(1,000,000$ in rats; West et al., 1991) of tightly packed granule cells and interneurons. Computational theories of hippocampal function have argued that the connectivity and dynamics of this structure lend themselves to efficient decorrelation of input from layer II of entorhinal cortex, whereby strong lateral inhibition ensures very few granule cells are allowed to fire at any given time, limiting the possibility of interference between stimuli or events with similar features by accentuating small differences (O'Reilly and McClelland, 1994; Leutgeb et al., 2007). Granule cells are often observed to have low average firing rates, and bimodal firing rate distributions with long periods of quiescence punctured by very high frequency bursts (Jung and McNaughton, 1993; Mistry et al., 2011). However, more recent studies provide evidence for subpopulations of granule cells that fire with more unimodal low frequency firing rates (Mistry et al., 2011), with electrophysiological and functional differences between populations found to correlate with maturity (Marín-Burgin et al., 2012; Nakashiba et al., 2012; Danielson et al., 2016). Adult born granule cells appear more excitable and less input specific yet better suited to pattern separation, whilst mature granule cells were found to be less excitable and more input specific yet better suited to pattern completion supporting a role for the dentate gyrus in both processes via separate populations of granule cells.

\subsection{Granule Cell Inputs to CA3 Pyramidal Cells}

Granule cell axons project sparsely to CA3 pyramidal cells (1 granule cell onto around 37 out of 300,000 pyramidal cells in rats; West et al., 1991; Acsády et al., 1998) and more diffusely to CA3 interneurons in the stratum lucidum. These axons, referred to as mossy fibers due to prominent en passant and large boutons, terminate onto CA3 pyramidal cells with large thorny excrescences located on the proximal region of apical and basal dendrites (Acsády et al., 1998; Wilke et al., 2013). These synapses possess 18-45 release sites and have enormous capacity for vesicle storage (Wilke et al., 2013). They are also noted for having low initial release probability but a wide time window for presynaptic facilitation of a few milliseconds to several seconds (Salin et al., 1996; Toth et al., 2000; Gundlfinger et al., 2007). Sufficiently long, albeit realistic, bursts of granule cell firing can elicit a presynaptic form of LTP that raises basal release probability but reduces the range of presynaptic shortterm facilitation (Zalutsky and Nicoll, 1990; Salin et al., 1996; Gundlfinger et al., 2007, 2010; Mistry et al., 2011). Collectively, this means the synapse has huge capacity for gain control over a wide range of input frequencies and has often been referred to as a "conditional detonator" due to its ability to elicit spikes in response to activity at a single synapse contingent on repeated stimulation. 


\subsection{Granule Cell Inputs to a Feedforward Interneuron Population}

Mossy fibers excite a diverse population of inhibitory interneurons located in the stratum lucidum, forming synapses via en passant boutons and small filopodia which protrude from large boutons directly onto interneuron dendrites (Acsády et al., 1998; Wilke et al., 2013), and this interneuron population has been shown to contribute to precision of memory encoding and retrieval (Ruediger et al., 2011; Restivo et al., 2015). Mossy fibers excite 10 times more interneurons than pyramidal cells, thus exerting strong widespread feedforward inhibitory control via a disynaptic pathway that prevents runaway excitation and ensures tight spike timing (Acsády et al., 1998; Mori et al., 2007; Torborg et al., 2010; Treviño et al., 2011).

However the identity and contribution of interneuron subtypes to feedforward mossy fiber driven inhibition is somewhat unclear. Szabadics and Soltesz (2009) identified ivy cells, parvalbumin-positive (PV+) fast spiking basket cells, and cholecystokinin-positive $(\mathrm{CCK}+)$ regular spiking basket cells as key contributing interneurons, while Toth et al. (2000) found a separation between interneurons with calcium permeable $(\mathrm{CP})$ or impermeable (CI) AMPA receptors. The overlap between these subtypes in CA3 is unclear, but in other hippocampal regions CP-AMPARs are preferentially expressed on $\mathrm{PV}+$ interneurons, and CI-AMPARS on CCK+ interneurons (Nissen et al., 2010). Characteristics of these cell types are summarized in Table $\mathbf{1}$.

These interneuron subtypes may perform distinct functional roles. Although PV+ basket cells receive weak mossy fiber input, they also receive a high rate of spontaneous excitation that may tonically depolarize them such that weak fluctuations are sufficient to synchronously activate a subset of their total population to provide tight control of pyramidal cell spike timing (Szabadics and Soltesz, 2009; Szabó et al., 2010; Torborg et al., 2010). However, mossy fiber drive to the PV+ basket cell network in CA3 can be vastly strengthened during learning by increased filopodial growth from mossy fiber boutons onto these interneurons (Ruediger et al., 2011; Donato et al., 2013). On the other hand, CCK + interneurons are excited by much stronger mossy fiber input but release GABA asynchronously, providing a tonic shunt, which may be reduced by release of endocannabinoids from CA3 pyramidal cells caused by an increase in spike frequency (Losonczy et al., 2004; Szabadics and Soltesz, 2009; Szabó et al., 2010). Finally, ivy cells target more distal portions of dendrites compared to basket cells and mossy fibers, which may provide some compartmental isolation in favor of mossy fiber transmission by suppressing the influence of upstream dendritic activation by competing excitatory pathways. These putative functional roles for interneuron subtypes are still largely speculative and are key areas for investigation.

\subsection{The CA3 Pyramidal Cell Network}

Feedforward monosynaptic excitation and disynaptic inhibition by mossy fiber input combine to selectively activate a small subpopulation of CA3 pyramidal cells (Mori et al., 2004) driving a transient phase coupling of DG-CA3 subnetworks (Akam et al., 2012). Many researchers have proposed that recurrent synapses amongst CA3 pyramidal cells endow the CA3 network with autoassociative and heteroassociative properties
(Marr, 1971; Treves and Rolls, 1994; Lisman, 1999; Bush et al., 2010; Savin et al., 2014; Guzman et al., 2016) such that ensembles of strongly associated CA3 pyramidal cells can be reactivated when only a subset of their constituent CA3 pyramidal cells have been activated by external sources. This mechanism is used to store and retrieve memories (Treves and Rolls, 1994; Lisman, 1999; Bush et al., 2010) via NMDA receptor (NMDAR)-dependent Hebbian plasticity (Nakazawa et al., 2004; Nakashiba, 2008; Mishra et al., 2016) that encodes memories as configurations of synaptic efficacies in the network, and retrieves them by precisely timed reactivation of cell ensembles stored as network motifs within these configurations. Stability, precision, and efficiency of this mechanism amidst uncertainty is supported by local oscillations that isolate subnetworks and encode memories by phase, and through subtle changes to intrinsic excitability of neurons during encoding and retrieval (Kunec et al., 2005; Lengyel et al., 2005; Lengyel and Dayan, 2007; Savin et al., 2014). Since mossy fiber synapses provide highly targeted sparse activation of subpopulations of CA3 pyramidal cells they are believed by some to be capable of driving both encoding and retrieval, by imposing synchronization necessary for driving Hebbian plasticity between CA3 pyramidal cells to establish ensembles (Kobayashi and Poo, 2004; Brandalise and Gerber, 2014; Mishra et al., 2016). Mossy fibers can also reactivate these CA3 ensembles at a later timepoint by triggering a local cascade of transient ensemble synchronization.

\section{NEUROMODULATION OF DG-CA3 MICROCIRCUIT}

\subsection{Acetylcholine}

\subsubsection{Release and Receptors}

Acetylcholine affects the dentate gyrus-CA3 microcircuit through the activity of muscarinic and nicotinic ACh receptors, and is delivered to the hippocampus by cholinergic cells projecting from the medial septum. Cholinergic fibers innervate the stratum oriens of CA3 and inner molecular layer of the dentate gyrus, and thin fibers have been found to innervate the stratum lucidum and hilar region (Kitt et al., 1994; Grybko et al., 2011).

Four muscarinic receptor subtypes are expressed in the hippocampus, but the main effects are driven through M1 and M2 receptors. M1 receptors are located on somatic and dendritic membranes of dentate gyrus granule cells and CA3 pyramidal cells (Levey et al., 1995; Dasari and Gulledge, 2011; Martinello et al., 2015), on mossy fibers (Martinello et al., 2015), and PV+ basket cells (Chiang et al., 2010; Yi et al., 2014). These receptors couple to Gq proteins and stimulate the phospholipase $\mathrm{C}$ signaling pathway to increase intracellular IP3 and DAG. M2 receptor expression has been found on stratum lucidum interneurons, and $\mathrm{PV}+$ basket cell axon terminals (Levey et al., 1995; Hájos et al., 1998) and sparsely on CA3 pyramidal cells (Levey et al., 1995), coupling to Gi proteins that reduce intracellular cAMP.

Nicotinic receptors are ligand gated cation channels with different functions depending on their affinity for ACh, desensitization kinetics, and permeability to calcium ions. 
TABLE 1 | Characteristics of mossy fiber feedforward interneuron-pyramidal cell plasticity in CA3.

\begin{tabular}{ll}
\hline Interneuron subtype & Forms of interneuron-pyramidal cell plasticity \\
\hline Cl-AMPAR containing & $\begin{array}{l}\text { Short-term facilitation of MF input (Toth et al., 2000). NMDAR-dependent LTD in response to high frequency stimulation via NMDARs } \\
\text { (Maccaferri et al., 1998). }\end{array}$ \\
CP-AMPAR containing & $\begin{array}{l}\text { Voltage dependent short term facilitation of MF input (Toth et al., 2000). mGluR7 -dependent LTD in response to high frequency stimulation } \\
\text { (Pelkey et al., 2005). }\end{array}$ \\
PV+ FSBC & $\begin{array}{l}\text { Weak short-term facilitation of mossy fiber input (Szabadics and Soltesz, 2009). Short-term depressing synchronous GABA release (Szabó } \\
\text { et al., 2010). } \\
\text { CCK+ RSBC }\end{array}$ \\
Strongly short-term depressing mossy fiber input (Szabadics and Soltesz, 2009). Short-term facilitating GABA release (Szabó et al., 2010). \\
Ivy & $\begin{array}{l}\text { Strong short-term depressing mossy fiber input. Dendritic targeting, dense axonal arborization (Szabadics and Soltesz, 2009). } \\
\end{array}$
\end{tabular}

Nicotinic receptors composed of five $\alpha 7$ subunits are widespread in the hippocampus, and have a high permeability to calcium ions, low affinity for nicotine, and undergo rapid desensitization. $\alpha 7$ receptors have been found on DG and CA3 interneurons (Son and Winzer-Serhan, 2008), on granule cell somas and dendrites, and sparsely in the stratum radiatum and stratum lucidum (Fabian-Fine et al., 2001). Furthermore, functional nicotinic receptors are more likely to be expressed on immature granule cells, and interneurons close to them (John et al., 2015). Although expression appears to be sparse, functional $\alpha 7$ nicotinic receptors have been detected in CA3 pyramidal cells, stratum lucidum interneurons, and mossy fiber synapses (Radcliffe et al., 1999; Frazier et al., 2003; Sharma and Vijayaraghavan, 2003; Sharma et al., 2008; Grybko et al., 2010, 2011). The evidence for other nicotinic receptor subtypes is less strong, although functional $\alpha 4 \beta 2$ and $\alpha 3 \beta 4$ receptors have been found on interneurons in CA1 (Jones and Yakel, 1997; McQuiston and Madison, 1999; Alkondon and Albuquerque, 2001; but see Gahring et al., 2004; Gahring and Rogers, 2008).

\subsubsection{Muscarinic Effects on Cellular and Synaptic Properties}

Excitability of granule cells, CA3 pyramidal cells, and PV+ basket cells, is strongly modulated by muscarinic activity. M1 receptors increase excitability and lower spike threshold of these cells by suppressing sAHP currents (Vogt and Regehr, 2001; Chiang et al., 2010; Dasari and Gulledge, 2011) and Kv7 (Martinello et al., 2015), thereby increasing the gain on any excitatory input. Furthermore, in CA3 pyramidal cells M1 receptors contribute to robust persistent firing following brief depolarization by activation of calcium sensitive non-selective ion channels (Jochems and Yoshida, 2013, 2015).

Muscarinic receptors also affect synaptic transmission in this circuit. M1 receptors indirectly suppress recurrent glutamatergic transmission between CA3 pyramidal cells, and GABAergic transmission from CCK + basket cells by stimulating the release of endocannabinoids from pyramidal cells, mossy cells, and granule cells to reduce presynaptic calcium influx and suppress vesicle release via presynaptic CB1 receptors (Hasselmo et al., 1995; Scanziani et al., 1995; Vogt and Regehr, 2001; Fukudome et al., 2004; Hofmann et al., 2006, 2008; Hofmann and Frazier, 2010; Szabó et al., 2010). Furthermore, M2 receptors suppress release from PV+ basket cells in DG and CA3 (Chiang et al., 2010; Szabó et al., 2010). These effects of muscarinic receptors collectively dampen recurrent activity in CA3, leaving cell dynamics to be driven primarily by feedforward and intrinsic mechanisms (Hasselmo et al., 1995; Jochems and Yoshida, 2015).

The mossy fiber synapse is indirectly modulated by muscarinic receptor activity. Due to increased granule cell firing frequency mossy fiber synapses become stronger through frequency facilitation (Vogt and Regehr, 2001). On the other hand, due to increased interneuron firing frequency, build up of extrasynaptic GABA concentration weakly suppresses mossy fiber synapses through GABA-B receptor activation (Vogt and Regehr, 2001; Chandler et al., 2003; Nahir et al., 2007). Additionally, since extrasynaptic GABA can also help induction of mossy fiber LTP and enhance transmission through modulation of calcium influx by high affinity delta subunit containing GABA-A receptors (Ruiz et al., 2010), the effect of extrasynaptic GABA may be biphasic. Since these processes occur on different time scales, it may be expected to see a transient indirect potentiation of mossy fiber synapses, followed by suppression in response to tonic muscarinic activity. These indirect effects on mossy fiber plasticity can account for experiments suggesting a direct effect of muscarinic receptors (Williams and Johnston, 1988, 1990).

M1 receptor activity has also been demonstrated to be key to enabling Hebbian NMDAR-dependent LTP between pyramidal cells in the hippocampus by inhibition of SK channels to increase spine calcium influx (Müller and Connor, 1991; Buchanan et al., 2010; Giessel and Sabatini, 2010). This effect on synaptic plasticity has mainly been studied in CA1, and some differences with CA3 have been found. For example, CA3 pyramidal cells internalize more NMDARs in response to increases in intracellular calcium concentration through IP3 activation, which can induce LTD (Grishin et al., 2004, 2005). Additionally, muscarinic receptors have been implicated in inhibitory depression onto pyramidal cells through coactivation of presynaptic $\mathrm{M} 2$ and $\mathrm{CB} 1$ receptors that reduce GABA release by activation of CAMP/PKA signaling pathways (Ahumada et al., 2013). Notably, this form of plasticity was induced by the same theta-burst stimulation protocol that induces potentiation of glutamatergic synapses. However, this is counterbalanced by a postsynaptic inhibitory potentiation enabled by $\mathrm{M} 1$ receptors that causes an enhancement of $\alpha 5 \beta \gamma 2$ GABA-A receptors influencing sensitivity to both CCK+ and PV+ basket cells (Domínguez et al., 2014, 2015). 


\subsubsection{Nicotinic Effects on Cellular and Synaptic Properties}

The functional role of nicotinic receptors in this circuit is less clear cut. In CA3, $\alpha 7$ nicotinic receptors have small effects on recurrent excitatory and inhibitory synapses onto pyramidal cells, which complement muscarinic effects (Giocomo and Hasselmo, 2005; Liotta et al., 2011; Fischer et al., 2014). In the dentate gyrus, nicotine enhances LTP at medial perforant path (mPP)-DG synapses through $\alpha 7$ receptors, and co-activation of NMDA and mGluR5 to activate the ERK-PKA signaling pathway (Welsby et al., 2006, 2009; Ondrejcak et al., 2012). This LTP is likely to be suppressed by local inhibition that is further strengthened by nicotinic receptors (Frazier et al., 2003), but interestingly this may be opposed by recruitment of mossy cells to provide a selective local excitatory boost that may be sufficient to enable LTP amongst a smaller number of synapses (Hofmann and Frazier, 2010).

A striking effect of nicotinic receptors within this circuit is stimulation of action potential independent synaptic release. At mossy fiber synapses, despite low expression seen in stratum lucidum (Fabian-Fine et al., 2001), $\alpha 7$ receptor activity induces bursts of action potential independent multiquantal release by stimulation of calcium induced calcium release that is sufficient to elicit postsynaptic action potentials (Sharma and Vijayaraghavan, 2003; Sharma et al., 2008). Additionally, over a longer time scale, activity of $\alpha 7$ receptors have been shown to enhance mossy fiber release via PKA activation (Cheng and Yakel, 2014). Action potential independent release stimulated by nicotinic receptors has also been shown in interneurons, albeit through a different mechanism. Tang et al. (2011) demonstrated that $\alpha 3 \beta 4$ receptors induce GABA release at PV+ basket cell synapses by activating T-type calcium channels and calcium induced calcium release.

Nicotinic receptors may have a further role at mossy fiber synapses. Structural plasticity of mossy fiber synapses through growth of filopodia onto PV+ interneurons occurs during contextual fear conditioning tasks (Ruediger et al., 2011), and nicotinic receptors have been implicated in filopodial growth at thalamic axon growth cones (Rüdiger and Bolz, 2008). Since the dentate gyrus continually integrates immature granule cells into its population, these cells may possess machinery for nicotinic mediated filopodial growth, which may be supported by greater $\alpha 7$ expression in immature granule cells (John et al., 2015).

\subsubsection{Summary}

- Muscarinic receptors combine to directly increase cellular excitability in granule cells, CA3 pyramidal cells, and interneurons.

- Muscarinic receptors depress synaptic transmission at inhibitory synapses and recurrent excitatory synapses.

- Muscarinic receptors lower requirements for Hebbian LTP induction.

- Muscarinic receptors indirectly enhance and suppress mossy fiber synapses over different time scales.

- Nicotinic receptors enable (mPP)-DG LTP.

- Nicotinic receptors can induce action potential independent release at mossy fiber synapses.

\subsection{Noradrenaline}

\subsubsection{Noradrenaline Release and Receptors}

Noradrenaline is released into the hippocampus from locus coeruleus (LC) projections, with strong direct innervation onto granule cells and hilar mossy cells in the dentate gyrus, CA3 pyramidal cells, and PV+ interneurons in the stratum lucidum (Hörtnagl et al., 1991; Milner et al., 2000; Walling et al., 2012). LC firing is tightly correlated with behavioral state, and novel or emotive stimuli induce burst firing of LC neurons (Vankov et al., 1995), with the nature and saliency of the experience influencing the intensity and duration of firing (Sara, 2009).

NA influences hippocampal function through activation of three classes of adrenoreceptors: $\alpha 1-, \alpha 2-$, and $\beta$-ARs, all of which are G-protein coupled: $\alpha 1$-ARs are coupled to Gq proteins and increase intracellular IP3 and DAG; $\alpha 2$-ARs couple to Gi proteins that inhibit adenylyl cyclase and reduce intracellular cAMP; whereas $\beta$-ARs stimulate Gs proteins that subsequently activate adenylyl cyclase and increase intracellular cAMP. $\beta$ ARs in CA3 show expression on cell membranes at somas and proximal dendrites of pyramidal cells, and subcellularly in the cytoplasm and nucleus (Jurgens et al., 2005; Guo and Li, 2007). Pre- and postsynaptic expression has been reported in the dentate gyrus on granule cells and interneurons (Milner et al., 2000), with $\beta 1$-ARs expressed in PV+ DG interneurons and $\beta 2$-ARs in NPY+ DG interneurons (Cox et al., 2008). In CA3, $\beta 1$ $\mathrm{AR}$ expression has been found on $\mathrm{CCK}+$ interneurons (Cox et al., 2008). Although the functional effects of these receptors on interneurons is severely understudied, the distinct cellular expression profiles of these receptors suggest various modulatory roles of $\beta$-ARs in inhibitory transmission.

\subsubsection{Noradrenergic Effects on Cellular and Synaptic Properties}

The effects of NA on cellular excitability are fairly modest, however NA typically hyperpolarizes and decreases the input resistance of CA3 pyramidal cells and dentate gyrus granule cells. Conversely, a small sub population also show depolarization and increased input resistance (Madison and Nicoll, 1986; Lacaille and Schwartzkroin, 1988; Ul Haq et al., 2012). These distinct effects are mediated by $\alpha$ - and $\beta$-ARs, respectively, with a $\beta$ $\mathrm{AR}$ mediated reduction in resting $\mathrm{K}^{+}$conductance likely causing depolarization (Lacaille and Schwartzkroin, 1988). Since a2AR activates Gi channels known to increase GIRK conductance (Sodickson and Bean, 1996; Lüscher et al., 1997), a2-AR activity may explain the hyperpolarizing effect of noradrenaline on hippocampal neurons, which reduces gain on excitatory glutamatergic transmission.

In the dentate gyrus, both inhibitory and excitatory hilar interneurons receive noradrenergic input (Milner and Bacon, 1989). In response to $\beta$-AR activation, both increase their firing rates, and inhibitory interneurons also show an attenuated sAHP (Bijak and Misgeld, 1995). $\alpha 1-\mathrm{AR}$ and $\alpha 2$-AR activation may attenuate discharges in inhibitory interneurons via hyperpolarization mechanisms (Bijak and Misgeld, 1995). The increased frequency of TTX-insensitive EPSPs and IPSPs observed in granule cells suggest that $\beta$-AR activation on both hilar interneuron types acts to increase presynaptic GABA and 
glutamate release. Interestingly, mixed $\alpha$ - and $\beta$-AR activation does not increase spontaneous discharge frequency, suggesting that $\alpha$-AR activity can counteract $\beta$-AR effects. This may result from differing affinity to NA of each adrenoreceptor, meaning that the synaptic concentration of NA determines the direction of modulation via activation of distinct adrenoreceptor subtypes. Indeed lower concentrations have been found to be excitatory, whilst higher concentrations are inhibitory (Jurgens et al., 2005). This seems strange given that $\beta 1$ receptors have lower affinity than $\alpha 2$-ARs (Ramos and Arnsten, 2007); however, this may be due to the greater proportion of $\beta$-ARs available for binding.

$\beta$-ARs enhance both NMDAR-dependent LTP and mossy fiber-LTP (Huang and Kandel, 1996; Gelinas, 2005). In the case of NMDAR-dependent LTP, this effect seems to occur both preand postsynaptically. Postsynaptically, $\beta$-ARs have been found to suppress sAHP currents, in turn increasing $\mathrm{Ca}^{2+}$ influx in granule cell and pyramidal cell synapses, reminiscent of M1 receptor effects (Madison and Nicoll, 1982; Haas and Konnerth, 1983; Haas and Rose, 1987; Pedarzani and Storm, 1993; Ul Haq et al., 2012). Furthermore, NA release during emotive stimuli have been found to facilitate the induction of LTP at pyramidal cell synapses by phosphorylation and subsequent trafficking of GluR1 containing AMPARs (Hu et al., 2007). It should be noted that in these LTP studies, adrenergic agonists were applied for $\geq 20$ min, which may not correlate with NA levels following transient LC burst firing during novel or emotional stimuli. Burst activation of the LC has been shown to induce long-term heterosynaptic facilitation at perforant path synapses, reliant on $\beta$-AR activation (Walling and Harley, 2004). NA release can outlast LC firing in novel environments (McIntyre et al., 2002) and is regulated by presynaptic glutamate release onto LC terminals (Wang et al., 1992) such that extracellular NA release increases in response to perforant path high frequency stimulation (Bronzino et al., 2001).

Activation of presynaptically located $\beta$-ARs within the dentate gyrus at perforant path and mossy fiber terminals increases glutamate release (Lynch and Bliss, 1986), which is thought to be due to increased presynaptic calcium influx through L- and N-type calcium channels (Gray and Johnston, 1987). These presynaptic effects of $\beta$-ARs also enhance mossy fiber-LTP (Hopkins and Johnston, 1984, 1988). PKA activation via $\beta$-ARs is critical for both early and late phases of mossy fiber-LTP (Huang and Kandel, 1996) and pyramidal cell synapses (Gelinas, 2005; Gelinas et al., 2008). This process is likely to be dependent on phosphorylation of synapsin 1 and 2, both involved in the vesicle release process (Parfitt et al., 1991, 1992).

Together, the effects of $\beta$-ARs appear to enhance disynaptic entorhinal drive of CA3 via the dentate gyrus. Indeed, selective NA fiber lesions via 6-OHDA treatment reduce perforant pathDG LTP in vivo and in vitro (Bliss et al., 1983) and $\beta$-AR activation converts sub-threshold mossy fiber-LTP tetanus to supra-threshold (Huang and Kandel, 1996). Furthermore, this does not appear to affect recurrent CA3 synapses and is not influenced by GABA receptor activity (Huang and Kandel, 1996). It is interesting to note that other neuromodulators capable of raising intracellular cAMP, e.g., 5-HT, did not allow such LTP to be expressed, indicating the possible involvement of additional lateral signaling pathways.
Little research has addressed the role of $\alpha$-ARs in the mossy fiber-CA3 microcircuit, however $\alpha 1$-ARs do reduce CA3 pyramidal cell sensitivity to mossy fiber transmission, without altering AMPAR sensitivity to glutamate (Scanziani et al., 1993) suggesting a presynaptic locus of action. However, $\alpha 1$-ARs can also enhance evoked NMDAR responses (Segal et al., 1991). Furthermore, $\alpha 1$-ARs appear to reduce basal release by decreasing presynaptic $\mathrm{Ca}^{2+}$ influx at mossy fiber-CA3 and recurrent CA3 synapses, but enhancing paired-pulse facilitation (Scanziani et al., 1993; Ul Haq et al., 2012). However, as with other neuromodulators, this effect may be indirect.

\subsubsection{Summary}

- NA largely decreases cellular excitability in principal cells, but occasionally increases excitability.

- NA facilitates induction of Hebbian LTP.

- NA enables mPP-DG LTP.

- NA enhances mossy fiber synaptic transmission.

- NA ensures persistence of LTP.

\subsection{Dopamine}

\subsubsection{Dopamine Release and Receptors}

Dopamine is released into the DG-CA3 microcircuit via projections from the Ventral Tegmental Area (VTA) and Substantia Nigra (SNc) (Gasbarri et al., 1994, 1997) and is associated with rewarding or novel stimuli. DA may also be released by noradrenergic fibers projecting from the locus coeruleus (LC) where it is stored in these afferents as a precursor (Smith and Greene, 2012) and DA antagonists can block the functional effects of LC stimulation in the hippocampus (Lemon and Manahan-Vaughan, 2012; Takeuchi et al., 2016). Furthermore, since DA reuptake transporters do not appear to be widely expressed in the hippocampus (Kwon et al., 2008), low levels of DA release could lead to extended periods of signaling.

DA receptors can be classified into two classes and five subtypes. D1 and D5 (D1-like) receptors that act to increase adenylate cyclase and cAMP, and D2-4 (D2-like) that decrease adenylate cyclase and cAMP (Missale et al., 1998). With developments in creating lines of transgenic mice, it has been easier to determine which cell types express particular subtypes. In the DG-CA3 microcircuit, D1 receptors are expressed on mature granule cells and CA3 interneurons (Gangarossa et al., 2012; Sariñana et al., 2014), while D5 is expressed on CA3 pyramidal cells and DG granule cells (Sariñana et al., 2014). Meanwhile, D2 receptors have been shown to be expressed strongly on hilar mossy cells and sparsely on CA3 interneurons, including PV + basket cells and NPY + ivy cells (Gangarossa et al., 2012; Etter and Krezel, 2014; Puighermanal et al., 2015). Overall, DA receptors are expressed more strongly in DG than CA3 (Ginsberg and Che, 2005), leading to the proposal that dopaminergic modulation of hippocampal function is primarily mediated by changes to DG function.

\subsubsection{Dopaminergic Effects on Cellular and Synaptic Properties}

Evidence for effects of DA on cellular excitability in this circuit is limited. D1 receptor activity in dentate gyrus granule cells mediate enhancement of after-depolarization increasing the 
likelihood of bursts (Hamilton et al., 2010). Although typically inhibitory, D2 receptors increase excitability of hilar mossy cells through inhibition of SK3 channels (Etter and Krezel, 2014). This selective enhancement of mossy cell transmission may increase recurrent activity in the dentate gyrus, particularly along the dorso-ventral axis, which may be important for sequence learning.

Basal mossy fiber transmission is enhanced by D1/D5 receptor activation, and paired pulse facilitation is reduced (Kobayashi et al., 2006; Kobayashi and Suzuki, 2007) indicating a presynaptic action dependent on intracellular cAMP elevation (Tzounopoulos et al., 1998). However, Gangarossa et al. (2012) found no evidence of D1 receptors on mossy fiber boutons, possibly suggesting heterosynaptic spillover-mediated facilitation via presynaptic and extrasynaptic GABA-A, GABA-B, and kainate receptors (Vogt and Regehr, 2001; Chandler et al., 2003; Contractor et al., 2003; Ruiz et al., 2010).

Dopaminergic transmission may also influence inhibition in this circuit. Tonic enhancement of feedforward inhibition via D4 receptors has been reported in DG and CA1 interneurons (Romo-Parra et al., 2005; Rosen et al., 2015) although this may not be present in CA3 interneurons. However, D1/D5 activation has been found to enhance PV+ basket cell plasticity in CA3, which was further shown to be necessary for consolidation of new memories (Karunakaran et al., 2016).

A key component of the effect DA has on the DGCA3 microcircuit is on plasticity in the mPP input to DG, primarily mediated through D1 receptors. Hamilton et al. (2010) demonstrated that increased dendritic excitability mediated by D1 activity facilitated induction of LTP in MPP-DG synapses, and Yang and Dani (2014) found that D1/D5 agonism alters STDP to convert pre-post intervals from depressing to potentiating, biasing the synapse toward potentiation overall and broadening the time window of STDP via inhibition of A-type $\mathrm{K}^{+}$channels. Dopaminergic activity also appears to ensure the persistence of LTP. Sariñana et al. (2014) showed a deficit in late-LTP at this synapse in anesthetized D1 and D5 knockout mice, and D1/D5 activation can prevent low frequency stimulation induced depotentiation (Kulla and Manahan-Vaughan, 2000). This is similar to the effect of combined $\alpha 1$ - and $\beta$-AR activation observed in CA1 (Katsuki et al., 1997). Furthermore, D1/D5 antagonism has been found to prevent the persistence of LTD at this synapse (Wiescholleck and Manahan-Vaughan, 2014) indicating that the effects of DA may be to promote persistence of plasticity regardless of sign. Collectively, DAdependent synaptic plasticity facilitates the recruitment of larger ensembles of granule and pyramidal cells in context learning as shown by c-fos expression (Sariñana et al., 2014).

\subsubsection{Summary}

- DA enhances mossy cell excitability.

- DA enables mPP-DG LTP induction.

- DA enhances mossy fiber synaptic transmission.

- DA facilitates inhibitory plasticity.

- DA ensures persistence of LTP.

\subsection{Serotonin}

\subsubsection{Serotonin Release and Receptors}

The hippocampal formation receives serotonergic innervation from the median and dorsal raphe nuclei (MRN and DRN respectively) of the rostral serotonergic raphe system (Törk, 1990; Gulyás et al., 1999; Leranth and Hajszan, 2007). Axons of the MRN 5-HT neurons (M fibers) are thick with large irregular varicosities, and make classical synaptic connections. These innervate the hippocampus on its entire dorso-ventral axis, terminating in the subiculum, stratum lacunosum-moleculare in CA1-CA3, stratum radiatum and oriens in CA2 and CA3, and in the polymorphic layer of the dentate gyrus. 5-HT neurons in the DRN send an extensively ramified, diffuse system of thin axons with many spindle-like varicosities (D-fibers) that mostly innervate the stratum lacunosum-moleculare and the polymorphic layer of the dentate gyrus. Delivery of 5-HT to the hippocampus depends on the firing of serotonergic cells, which have been found to fire at a constant $3 \mathrm{~Hz}$ rate during quiet wake, but increase two to five-fold during repetitive motor activity, e.g., running, and fall largely silent during REM sleep and in the presence of novel attention-orienting stimuli (Jacobs and Fornal, 1999), however local raphe circuits may interact to deliver 5-HT to regions of the brain at different volumes.

There are currently at least 14 known distinct subtypes of 5-HT receptor, of which all are G protein coupled except 5HT3 (Barnes and Sharp, 1999; Millan et al., 2008; Berumen et al., 2012), with many of them found to be functionally expressed in the DG-CA3 microcircuit. 5-HT1 receptor types couple to Gi/o proteins that inhibit adenylate cyclase and cAMP synthesis, and one important subtype (5-HT1A) is highly expressed somatodendritically on CA3 pyramidal cells, dentate granule cells, and PV+ interneurons (Pazos et al., 1985; Andrade et al., 1986; Chalmers and Watson, 1991; Aznar et al., 2003). 5HT2A and 5-HT2C receptors couple via Gq/11 to the IP3/PLC signaling pathway, and have been found on granule cells, pyramidal cells, and interneurons in DG and CA3 ( $\mathrm{Li}$ et al., 2004; Bombardi, 2012). 5-HT4 and 5-HT7 receptors couple to Gs proteins and promote cAMP synthesis, with both expressed on granule cells and pyramidal cells, and 5-HT7 receptors specifically on CA3 pyramidal cells (Vilaró et al., 1996, 2005; Suwa et al., 2014); however, expression of 5-HT4 decreases during memory consolidation (Manuel-Apolinar et al., 2005). Finally, 5HT3 receptors are ligand gated non-selective cation channels that belong to the same superfamily as nicotinic, GABA, and glycine receptors, and have been found on CCK + basket cells, providing a fast depolarizing inward current (Freund et al., 1990; McMahon and Kauer, 1997; Gulyás et al., 1999).

\subsubsection{Serotonergic Effects on Cellular and Synaptic Properties}

5-HT1A receptors mediate a strong hyperpolarizing effect of 5HT on granule cells and pyramidal cells through activation of GIRK channels (Andrade and Nicoll, 1987; Beck et al., 1992; Okuhara and Beck, 1994; Piguet and Galvan, 1994; Twarkowski et al., 2016; Ul Haq et al., 2016), reducing firing frequency, and dampening gamma oscillations (Twarkowski et al., 2016). This hyperpolarization is opposed by activation of 5-HT4 receptors on 
pyramidal and granule cells, and 5-HT7 receptors on pyramidal cells that inhibit sAHP currents to increase firing frequency (Bacon and Beck, 2000). Collectively, findings from in vitro pharmacology studies suggest that the net effect of 5-HT in CA3 is widely inhibitory, but 5-HT also influences neuronal gain whereby weak excitatory stimuli are suppressed and strong excitatory stimuli are enhanced (Andrade et al., 1986; Beck et al., 1992; Villani and Johnston, 1993). In the dentate gyrus however, the distribution of 5-HT1A receptors along granule cell dendrites induces a shunting inhibition that blocks lateral PP over medial PP input (Nozaki et al., 2016). It is important to note that the balance of hyperpolarizing and depolarizing effects of 5-HT will depend on the local concentration of 5-HT available given the varying density and affinity of receptors.

The effects of 5-HT on synaptic transmission have been somewhat contradictory. Some studies have found that 5-HT prevents the induction of NMDAR dependent LTP (Villani and Johnston, 1993) due to the hyperpolarizing effect on pyramidal cells. However, when administered at concentrations that do not hyperpolarize cells 5-HT4 receptor activation is found to prevent mPP-DG LTD and curtail established LTP (Twarkowski et al., 2016). Furthermore, release of endogenous 5-HT via MDMA application has been found to facilitate LTP induction (Mlinar et al., 2015). 5-HT2 receptors have also been found to mediate synaptic facilitation via a PLC pathway by preor postsynaptic mechanisms, but this may also be occluded by an increase in GABAergic synaptic activity that diffuses extrasynaptically to tonically inhibit this effect (Zhang and Stackman, 2015). Altogether, it is highly unclear what the likely effect of endogenously released 5-HT under naturalistic conditions is likely to have on the induction of long term plasticity.

At the mossy fiber synapse, 5-HT4 activation has been found to prevent both LTP and LTD at 5-HT concentrations that do not hyperpolarize cells. Earlier studies also found that 5HT3 receptor activity prevents mossy fiber LTP (Maeda et al., 1994), which is likely due to recruitment of CCK+ basket cells that fire asynchronously to tonically inhibit CA3 pyramidal cells. Furthermore, 5-HT1A and 5-HT4 receptors modulate mossy fiber synaptic transmission, as the NMDAR-mediated EPSC components are enhanced by 5 -HT4 activity, and are concurrently mildly suppressed by a longer lasting 5-HT1A effect (Kobayashi et al., 2008).

\subsubsection{Summary}

- 5-HT is principally hyperpolarizing.

- 5-HT can both enhance or suppresses Hebbian LTP.

- 5-HT suppresses IPP-DG synapses.

- 5-HT can both enhance or suppress mossy fiber transmission.

\section{IMPLICATIONS FOR THEORIES OF NEUROMODULATION AND MEMORY ENCODING AND RETRIEVAL}

Theories and computational models of memory encoding and retrieval in the hippocampus often compromise between incorporating features of observed behavior (top-down) either as memory task performance or network dynamics, and circuit dynamics at the cellular level (bottom-up) in terms of excitability of cellular membranes and synaptic plasticity. In this review we have broadly outlined results on the latter components of these theories. The net effect of neuromodulators is often difficult to predict as receptor subtypes may have apparently opposing effects, or may take place over distinct time scales. As such, the net effects and implications for encoding and retrieval are ideally placed for investigation through computational modeling. In this section, we review computational models of DG-CA3 network function in encoding and retrieval that have incorporated features of neuromodulation, and discuss how these models can be adapted and extended to include multiple neuromodulatory systems or incorporate further features of excitability and plasticity that have received little theoretical treatment. In particular, since cholinergic neuromodulation has received the most extensive consideration, but shares many mechanisms of action with other neuromodulatory systems, it will be used as a starting point to suggest how other neuromodulators may influence encoding and retrieval through changes to excitability and plasticity.

\subsection{Encoding: Learning Conditions}

Several theories argue that ACh is essential for learning new informations patterns through a variety of mechanisms. One family of theories inspired by Marr's theory of archicortex (Marr, 1971) propose that ACh selectively enhances information flow through DG-CA3 to decorrelate and sparsify entorhinal information, reducing interference during encoding (Hasselmo, 2006; Hummos et al., 2014). However, others have proposed that through enhancement of the power of theta and gamma rhythms, ACh opens tightly controlled windows for spike timingdependent plasticity (STDP) driven by either afferent input to form associations (Kunec et al., 2005; Bush et al., 2010; Jochems and Yoshida, 2015). Furthermore, ACh also increases excitability which favors pre- and postsynaptic burst firing necessary to activate STDP (Bush et al., 2010; Jochems and Yoshida, 2015; Saravanan et al., 2015).

NA may play a similar role as ACh by creating an environment ripe for encoding through the actions of $\beta$ ARs, since they similarly suppress sAHP currents that lowers the induction threshold for NMDAR-dependent plasticity and enhance excitability in a subpopulation of neurons (Madison and Nicoll, 1982; Pedarzani and Storm, 1993; Gelinas, 2005; Ul Haq et al., 2012). However, in contrast with ACh, this enhancement in excitability is not as widespread providing a more conservative encoding system. Likewise, although 5-HT may help to induce synaptic plasticity through 5-HT2, 5-HT4, or 5-HT7 receptors, due to common signaling pathways, some coordinated disinhibition or relief from strong hyperpolarization may need to take place to permit this, making any learning via 5 -HT even more conservative. DA on the other hand, may have a similarly liberal encoding system to ACh, albeit restricted to dentate gyrus granule cells where expression of DA receptors is greatest (Hamilton et al., 2010), and may confer the ability to encode delayed associations by broadening the STDP window to include potentiating post-pre pairs (Yang and Dani, 2014). 
Much of our knowledge about synaptic plasticity is inferred from studies using prolonged high frequency stimulation, although STDP is thought to be a more biologically realistic stimulation paradigm. Since the key trigger for synaptic plasticity is calcium influx into postsynaptic spines, understanding how neuromodulators gate this process via control of nanodomain calcium concentration to trigger common calcium dependent signaling pathways (Buchanan et al., 2010; Giessel and Sabatini, 2010; Griffith et al., 2016; Tigaret et al., 2016) will be critical to provide a better understanding of encoding under biologically relevant conditions.

\subsection{Encoding: Novelty Detection}

The hippocampus favors the encoding of neuronal ensembles in novel situations and neuromodulators are proposed to achieve this encoding by reducing the threshold for novelty detection. A recent model proposed a mechanism in which novelty is detected via the relative timing of DG and CA3 firing, i.e., if CA3 fires before DG then the stimulus is familiar so no learning should take place (Nolan et al., 2011). In this scenario, ACh and DA lower the threshold for novelty detection by selectively enhancing the EC-DG-CA3 pathway, thereby speeding up transmission and triggering encoding more often (Nolan et al., 2011). This theory is supported by the finding that CA3 pyramidal cells can activate a disinhibitory circuit via the lateral septum to promote DA release from the VTA (Luo et al., 2011). Similarly, earlier models of novelty detection proposed that new patterns would be filtered out by the dentate gyrus, reducing CA3 firing and promoting ACh release by disinhibiting the medial septum (Meeter et al., 2004). Conversely, when 5-HT is introduced, the hyperpolarizing effect of 5-HT1ARs dominates information flow in this circuit, and raises the novelty detection threshold (Meeter et al., 2006). Finally, NA may increase or decrease novelty detection thresholds due to the mixture of hyperpolarization and enhancement of the EC-DG-CA3 pathway.

\subsection{Information Flow}

It is useful to consider how the effects of neuromodulators on excitability and plasticity relate to gain modulation and signal-tonoise ratio through the combined action of GIRK enhancement and sAHP suppression. Each of the neuromodulators act through these potassium channels to regulate excitability and this balance is important for understanding how information flows through this circuit in different configurations. Through inward rectification, GIRK channel activation provides shunting inhibition at rest that attenuates toward threshold, while sAHP current suppression increases firing frequency. Collectively, these effects can be predicted to suppress weak synaptic input and increase the gain on strong synaptic input, further increasing the likelihood of bursts with strong synaptic input. This effectively increases signal far above noise, and may facilitate propagation of coordinated recurrent activity.

In contrast, ACh primarily suppresses sAHP currents increasing the likelihood of spontaneous spiking across excitatory and inhibitory cells thereby increasing both signal and noise, which may effectively drown out competing streams of information with noise. This may be a particular mechanism through which strongly fluctuating afferent input, e.g., mossy fibers or synchronous perforant path input, are favored over weakly fluctuating inputs e.g., recurrent or asynchronous perforant path input. For other neuromodulatory systems, 5-HT may increase signal with respect to noise more weakly than NA whereas DA may act similarly to NA, but with greater restriction to the dentate gyrus as opposed to CA3 due to higher expression of $\mathrm{D} 1$ receptors in dentate gyrus.

\subsection{Autoassociation (Pattern Completion)}

In theories proposing that ACh supports pattern separation, it is often also proposed to suppress pattern completion due to presynaptic inhibition of recurrent collaterals (Hasselmo, 2006; Hummos et al., 2014). However, when incorporating the effects of ACh on intrinsic excitability, pattern completion in CA3 is actually more robust due to intrinsically driven bursting, despite suppressed recurrent synapses (Jochems and Yoshida, 2015). Furthermore, distal inhibition keeps burst propagation local, allowing pattern completion amongst small networks (Saravanan et al., 2015). Theta-driven models of retrieval in which encoding and retrieval take place within one cycle of the theta rhythm, propose that ACh enhances the theta rhythm and for half a cycle disinhibits OLM cells that inhibit perforant path inputs to CA3 pyramidal cells and render mossy fiber cued autoassociative dynamics dominant (Kunec et al., 2005).

Alternative theories propose that pattern completion takes place in the dentate gyrus, when mossy cells are activated to provide feedback excitation (Lisman, 1999; Lisman and Otmakhova, 2001). Granule cells have been shown to participate in pattern completion (Leutgeb et al., 2007), and DA may have a role in converting the dentate gyrus from pattern separation to pattern completion mode by increasing the excitability of mossy cells via D2 receptors (Etter and Krezel, 2014).

\subsection{Retrieval: Heteroassociation (Sequence Completion)}

Some theories argue that the CA3 network plays a role in sequence completion (Lisman, 1999), and that sharp wave ripples, replay, preplay and phase precession are phenomena resulting from sequence completion. Within this context, ACh is proposed to suppress sequence completion since it suppresses recurrent collaterals necessary for fast replay, and suppresses AHP currents necessary to propagate signals unidirectionally with bidirectional synapses (Saravanan et al., 2015).

Furthermore, in vitro sharp wave ripples are bidirectionally influenced by NA via hyperpolarization of CA3 pyramidal cells and activation of excitability-enhancing plasticity-inducing $\beta$ ARs, meaning the spatial distribution of ARs may be important in determining the precision of both encoding and retrieval (Ul Haq et al., 2012). In contrast, ACh shifts ripple frequencies to gamma frequencies (Fischer et al., 2014), indicative of a switch from retrieval to encoding states. The effect of NA in this case is more similar to 5-HT, which largely suppresses sharp wave ripples through hyperpolarization induced by 5-HT1A receptors (U1 Haq et al., 2016). DA enhances sharp wave ripple replay, partly through plasticity of interneuron synapses (Miyawaki et al., 2014; 
Karunakaran et al., 2016). This suggests DA may push the DGCA3 system toward a retrieval dominated state of processing.

\subsection{Conclusions and Future Directions}

Modulation of excitability and plasticity within the DG-CA3 microcircuit by the neuromodulators described here is likely to alter its function. In this review we have outlined known mechanisms through which alterations can occur, and how these may relate to encoding and retrieval. There are many similarities between each type of neuromodulator and as such their effects may well take place in different regions of the same "state space." Here we have proposed a system in which each neuromodulator may favor encoding (ACh and $\mathrm{NA}$ ) or retrieval (DA and 5-HT), with greater likelihood of false positives (ACh and $\mathrm{DA}$ ) in a liberal state, and false negatives (NA and 5-HT) in a conservative state. These effects may take place through altering subthreshold integration and filtering of inputs via distinct potassium channel conductances, and selective augmentation of afferent synaptic pathways and synaptic noise.

Certain aspects of neuromodulatory effects have yet to be addressed in the dentate-CA3 microcircuit, for example, the shared role of NA and DA in ensuring the persistence of LTP at the mPP-DG synapse (Straube and Frey, 2003; Hamilton et al., 2010; Sariñana et al., 2014). This may be necessary to associate ensembles in sequence that are delayed over a longer period of time, or could be necessary to cue re-encoding and consolidation during subsequent retrieval. Likewise the effects of neuromodulators on interneuron excitability, plasticity, and function are rarely considered but are likely to be very important. In many theories, inhibitory networks are designed to produce a particular set of dynamics, introducing a heavy bias. Since plasticity in inhibitory networks has been shown to be sufficient to support encoding and retrieval in recurrent networks by fine tuning of excitatory-inhibitory balance (Vogels et al., 2011), a greater understanding of the role of neuromodulators within this framework could reduce such bias. For example, the recent finding that inhibitory plasticity of PV+ basket cells is enhanced by D1 receptors during memory consolidation (Karunakaran et al., 2016) may be through the enhancement of gamma power that allows repeated efficient retrieval of sequences.

Finally it is necessary to understand the spatio-temporal release profile of neuromodulators under physiological conditions to assess the validity of these theories. Much of our current knowledge is through pharmacological manipulation of excitability and plasticity in vitro, which may be well suited to understanding the steady state effect of neuromodulators, but is not so informative of dynamic neuromodulatory systems. For example, Rosen et al. (2015) used optogenetic stimulation of VTA and SNc terminals in the hippocampus to show biphasic effects of DA receptors in CA1, with tonic release increasing inhibitory drive by enhancing Schaffer Collateral excitation of PV+ basket cells via D4 receptors and phasic release increasing excitatory drive by enhancing Schaffer Collateral excitation of pyramidal cells via D1/D5 receptors. Previously, pharmacological activation of these receptors had been unable to uncover this biphasic effect. Such control may also be expected to be observed in the dentate gyrus given a similar distribution of DA receptors.

It is very likely that control of the DG-CA3 circuit by other neuromodulatory systems will also be sensitive to neuromodulator release profile. Varga et al. (2009) demonstrated that median raphe nuclei projections to the CA1 and CA3 rapidly recruit a powerful inhibitory network via mixed serotonergic-glutamatergic release that activates postsynaptic 5HT3 and glutamate receptors. Similarly, Grybko et al. (2011) showed that low frequency electrical stimulation of cholinergic fibers elicited fast nicotinic mediated depolarization of CA3 pyramidal cells and interneurons, which are typically occluded by rapid desensitization of $\alpha 7$ receptors with bath application of cholinergic agonists. The balance between muscarinic and nicotinic control of circuit function may therefore vary with the pattern of cholinergic delivery by the medial septum. High frequency locus coeruleus fiber stimulation has also been shown to modulate long-term depression and potentiation at mPP-DG synapses via $\beta$-AR activation, which may indicate that LC bursts during emotive, arousing, or novel stimuli "opens the gate" for mPP-DG plasticity (Hansen and Manahan-Vaughan, 2015a,b), and may contribute to any role the dentate gyrus performs in novelty detection.

Furthermore, neuromodulatory systems are known to interact such that co-release or sequentially co-ordinated release may be highly relevant to their circuit impact. For example, feedforward and feedback control of neuromodulatory systems between the habenula and the hippocampus has been shown with regards to serotonergic downregulation and cholinergic upregulation of the hippocampal theta rhythm (Aizawa et al., 2013; Goutagny et al., 2013), and 5-HT4 agonists delivered to the medial septum can increase ACh release to the hippocampus (Mohler et al., 2007). In such cases similar effects may saturate or augment each other, or opposing effects could cancel each other out. If there is a coding system of uncertainty, novelty, and salience related to these neuromodulators then these are likely represented through a dynamic neuromodulatory profile, whose dissection remains a fascinating topic of investigation.

\section{AUTHOR CONTRIBUTIONS}

All authors listed, have made substantial, direct and intellectual contribution to the work, and approved it for publication.

\section{FUNDING}

LP, CT, and JM supported by Wellcome Trust. TB, CT, and JM supported by Biotechnology and Biological Science Research Council.

\section{ACKNOWLEDGMENTS}

We thank members of the Mellor lab for discussion of ideas incorporated in this article. 


\section{REFERENCES}

Acsády, L., Kamondi, A., Sík, A., Freund, T. F., and Buzsáki, G. (1998). GABAergic cells are the major postsynaptic targets of mossy fibers in the rat hippocampus. J. Neurosci. 18, 3386-3403.

Ahumada, J., de Sevilla, D. F., Couve, A., Buño, W., and Fuenzalida, M. (2013). Long-term depression of inhibitory synaptic transmission induced by spiketiming dependent plasticity requires coactivation of endocannabinoid and muscarinic receptors. Hippocampus 23, 1439-1452. doi: 10.1002/hipo.22196

Aizawa, H., Yanagihara, S., Kobayashi, M., Niisato, K., Takakawa, T., Harukuni, R., et al. (2013). The synchronous activity of lateral habenular neurons is essential for regulating hippocampal theta oscillation. J. Neurosci. 33, 8909-8921. doi: 10.1523/JNEUROSCI.4369-12.2013

Akam, T., Oren, I., Mantoan, L., Ferenczi, E., and Kullmann, D. M. (2012). Oscillatory dynamics in the hippocampus support dentate gyrus-CA3 coupling. Nat. Neurosci. 15, 763-768. doi: 10.1038/nn.3081

Alkondon, M., and Albuquerque, E. X. (2001). Nicotinic acetylcholine receptor $\alpha 7$ and $\alpha 4 \beta 2$ subtypes differentially control GABAergic input to CA1 neurons in rat hippocampus. J. Neurophysiol. 86, 3043-3055. Available online at: http://jn. physiology.org/content/86/6/3043

Andrade, R., Malenka, R. C., and Nicoll, R. A. (1986). A G-protein couples serotonin and GABAB receptors to the same channels in hippocampus. Science 234, 1261-1265. doi: 10.1126/science.2430334

Andrade, R., and Nicoll, R. A. (1987). Pharmacologically distinct actions of serotonin on single pyramidal neurones of the rat hippocampus recorded in vitro. J. Physiol. 394, 99-124. doi: 10.1113/jphysiol.1987.sp016862

Aznar, S., Qian, Z., Shah, R., Rahbek, B., and Knudsen, G. M. (2003). The 5-HT1A serotonin receptor is located on calbindin- and parvalbumincontaining neurons in the rat brain. Brain Res. 959, 58-67. doi: 10.1016/S00068993(02)03727-7

Bacon, W. L., and Beck, S. G. (2000). 5-Hydroxytryptamine7 receptor activation decreases slow afterhyperpolarization amplitude in CA3 hippocampal pyramidal cells. J. Pharmacol. Exp. Ther. 294, 672-679. Available online at: http://jpet.aspetjournals.org/content/294/2/672

Barnes, N. M., and Sharp, T. (1999). A review of central 5-HT receptors and their function. Neuropharmacology 38, 1083-1152. doi: 10.1016/S00283908(99)00010-6

Beck, S. G., Choi, K. C., and List, T. J. (1992). Comparison of 5hydroxytryptamine1A-mediated hyperpolarization in CA1 and CA3 hippocampal pyramidal cells. J. Pharmacol. Exp. Ther. 263, 350-359.

Berumen, L. C., Rodriguez, A., Miledi, R., and Garcia-Alcocer, G. (2012). Serotonin receptors in hippocampus. ScientificWorldJournal 2012:823493. doi: $10.1100 / 2012 / 823493$

Bijak, M., and Misgeld, U. (1995). Adrenergic modulation of hilar neuron activity and granule cell inhibition in the guinea-pig hippocampal slice. Neuroscience 67, 541-550. doi: 10.1016/0306-4522(95)00086-X

Bliss, T. V. P., Goddard, G. V., and Riives, M. (1983). Reduction of long-term potentiation in the dentate gyrus of the rat following selective depletion of monoamines. J. Physiol. 334, 475-491. doi: 10.1113/jphysiol.1983.sp014507

Bombardi, C. (2012). Neuronal localization of 5-HT2A receptor immunoreactivity in the rat hippocampal region. Brain Res. Bull. 87, 259-273. doi: 10.1016/j.brainresbull.2011.11.006

Brandalise, F., and Gerber, U. (2014). Mossy fiber-evoked subthreshold responses induce timing-dependent plasticity at hippocampal CA3 recurrent synapses. Proc. Natl. Acad. Sci. U.S.A. 111, 4303-4308. doi: 10.1073/pnas.1317667111

Bronzino, J. D., Kehoe, P., Mallinson, K., and Fortin, D. A. (2001). Increased extracellular release of hippocampal NE is associated with tetanization of the medial perforant pathway in the freely moving adult male rat. Hippocampus 11 , 423-429. doi: 10.1002/hipo.1057

Buchanan, K. A., Petrovic, M. M., Chamberlain, S. E. L., Marrion, N. V., and Mellor, J. R. (2010). Facilitation of long-term potentiation by muscarinic M1 receptors is mediated by inhibition of SK channels. Neuron 68, 948-963. doi: 10.1016/j.neuron.2010.11.018

Bush, D., Philippides, A., Husbands, P., and O'Shea, M. (2010). Dual coding with STDP in a spiking recurrent neural network model of the hippocampus. PLoS Comput. Biol. 6:e1000839. doi: 10.1371/journal.pcbi.1000839

Chalmers, D. T., and Watson, S. J. (1991). Comparative anatomical distribution of 5-HT1A receptor mRNA and 5-HTIA binding in rat brain - a combined in situ hybridisation/in vitro receptor autoradiographic study. Brain Res. 561, 51-60. doi: 10.1016/0006-8993(91)90748-K

Chandler, K. E., Princivalle, A. P., Fabian-Fine, R., Bowery, N. G., Kullmann, D. M., and Walker, M. C. (2003). Plasticity of GABAB receptor-mediated heterosynaptic interactions at mossy fibers after status epilepticus. J. Neurosci. 23, 11382-11391. Available online at: http://www.jneurosci.org/content/23/36/ 11382

Cheng, Q., and Yakel, J. L. (2014). Presynaptic $\alpha 7$ nicotinic acetylcholine receptors enhance hippocampal mossy fiber glutamatergic transmission via PKA activation. J. Neurosci. 34, 124-133. doi: 10.1523/JNEUROSCI.297313.2014

Chiang, P. H., Yeh, W. C., Lee, C. T., Weng, J. Y., Huang, Y. Y., and Lien, C. C. (2010). M1-like muscarinic acetylcholine receptors regulate fast-spiking interneuron excitability in rat dentate gyrus. Neuroscience 169, 39-51. doi: 10.1016/j.neuroscience.2010.04.051

Contractor, A., Sailer, A. W., Darstein, M., Maron, C., Xu, J., Swanson, G. T., et al. (2003). Loss of kainate receptor-mediated heterosynaptic facilitation of mossyfiber synapses in $\mathrm{KA} 2^{-/-}$mice. J. Neurosci. 23, 422-429. Available online at: http://www.jneurosci.org/content/23/2/422

Cox, D. J., Racca, C., and LeBeau, F. E. N. (2008). alpha-adrenergic receptors are differentially expressed in distinct interneuron subtypes in the rat hippocampus. J. Comp. Neurol. 509, 551-565. doi: 10.1002/cne. 21758

Danielson, N. B., Kaifosh, P., Zaremba, J. D., Lovett-Barron, M., Tsai, J., Denny, C. A., et al. (2016). Distinct contribution of adult-born hippocampal granule cells to context encoding. Neuron 90, 101-112. doi: 10.1016/j.neuron.2016.02.019

Dasari, S., and Gulledge, A. T. (2011). M1 and M4 receptors modulate hippocampal pyramidal neurons. J. Neurophysiol. 105, 779-792. doi: 10.1152/jn.00686.2010

Domínguez, S., Fernández de Sevilla, D., and Buño, W. (2014). Postsynaptic activity reverses the sign of the acetylcholine-induced long-term plasticity of GABAA inhibition. Proc. Natl. Acad. Sci. U.S.A. 111, E2741-E2750. doi: 10.1073/pnas.1321777111

Domínguez, S., Fernández de Sevilla, D., and Buño, W. (2015). Acetylcholine facilitates a depolarization-induced enhancement of inhibition in rat CA1 pyramidal neurons. Cereb. Cortex. doi: 10.1093/cercor/bhv276. [Epub ahead of print].

Donato, F., Belluco Rompani, S., and Caroni, P. (2013). Parvalbumin-expressing basket-cell network plasticity induced by experience regulates adult learning. Nature 504, 272-276. doi: 10.1038/nature12866

Etter, G., and Krezel, W. (2014). Dopamine D2 receptor controls hilar mossy cells excitability. Hippocampus 24, 725-732. doi: 10.1002/hipo.22280

Fabian-Fine, R., Skehel, P., Errington, M. L., Davies, H. A., Sher, E., Stewart, M. G., et al. (2001). Ultrastructural distribution of the $\alpha 7$ nicotinic acetylcholine receptor subunit in rat hippocampus. J. Neurosci. 21, 7993-8003. Available online at: http://www.jneurosci.org/content/21/20/7993

Fischer, V., Both, M., Draguhn, A., and Egorov, A. V. (2014). Cholinemediated modulation of hippocampal sharp wave-ripple complexes in vitro. J. Neurochem. 129, 792-805. doi: 10.1111/jnc.12693

Frazier, C. J., Strowbridge, B. W., and Papke, R. L. (2003). Nicotinic receptors on local circuit neurons in dentate gyrus : a potential role in regulation of granule cell excitability nicotinic receptors on local circuit neurons in dentate gyrus : a potential role in regulation of granule cell excitability. J. Neurophysiol. 89, 3018-3028. doi: 10.1152/jn.01036.2002

Freund, T. F., Gulyás, A. I., Acsády, L., Görcs, T., and Tóth, K. (1990). Serotonergic control of the hippocampus via local inhibitory interneurons. Proc. Natl. Acad. Sci. U.S.A. 87, 8501-8505. doi: 10.1073/pnas.87.21.8501

Fuhs, M. C., and Touretzky, D. S. (2000). Synaptic learning models of map separation in the hippocampus. Neurocomputing 32-33, 379-384. doi: 10.1016/S0925-2312(00)00189-2

Fukudome, Y., Ohno-Shosaku, T., Matsui, M., Omori, Y., Fukaya, M., Tsubokawa, H., et al. (2004). Two distinct classes of muscarinic action on hippocampal inhibitory synapses: M2-mediated direct suppression and M1/M3-mediated indirect suppression through. Eur. J. Neurosci. 19, 26822692. doi: 10.1111/j.0953-816X.2004.03384.x

Gahring, L. C., Persiyanov, K., Dunn, D., Weiss, R., Meyer, E. L., and Rogers, S. W. (2004). Mouse strain-specific nicotinic acetylcholine receptor expression 
by inhibitory interneurons and astrocytes in the dorsal hippocampus. J. Comp. Neurol. 468, 334-346. doi: 10.1002/cne.10943

Gahring, L. C., and Rogers, S. W. (2008). Nicotinic acetylcholine receptor expression in the hippocampus of 27 mouse strains reveals novel inhibitory circuitry. Hippocampus 18, 737-749. doi: 10.1002/hipo.20430

Gangarossa, G., Longueville, S., De Bundel, D., Perroy, J., Hervé, D., Girault, J. A., et al. (2012). Characterization of dopamine D1 and D2 receptorexpressing neurons in the mouse hippocampus. Hippocampus 22, 2199-2207. doi: 10.1002/hipo.22044

Gasbarri, A., Sulli, A., and Packard, M. G. (1997). The dopaminergic mesencephalic projections to the hippocampal formation in the rat. Prog. Neuropsychopharmacol. Biol. Psychiatry 21, 1-22.

Gasbarri, A., Verney, C., Innocenzi, R., Campana, E., and Pacitti, C. (1994). Mesolimbic dopaminergic neurons innervating the hippocampal formation in the rat: a combined retrograde tracing and immunohistochemical study. Brain Res. 668, 71-79. doi: 10.1016/0006-8993(94)90512-6

Gelinas, J. N. (2005). Beta-adrenergic receptor activation facilitates induction of a protein synthesis-dependent late phase of long-term potentiation. J. Neurosci. 25, 3294-3303. doi: 10.1523/JNEUROSCI.4175-04.2005

Gelinas, J. N., Tenorio, G., Lemon, N., Abel, T., and Nguyen, P. V. (2008). Betaadrenergic receptor activation during distinct patterns of stimulation critically modulates the PKA-dependence of LTP in the mouse hippocampus. Learn. Mem. 15, 281-289. doi: $10.1101 / \mathrm{lm} .829208$

Giessel, A. J., and Sabatini, B. L. (2010). M1 muscarinic receptors boost synaptic potentials and calcium influx in dendritic spines by inhibiting postsynaptic SK channels. Neuron 68, 936-947. doi: 10.1016/j.neuron.2010.09.004

Ginsberg, S. D., and Che, S. (2005). Expression profile analysis within the human hippocampus: comparison of CA1 and CA3 pyramidal neurons. J. Comp. Neurol. 487, 107-118. doi: 10.1002/cne.20535

Giocomo, L. M., and Hasselmo, M. E. (2005). Nicotinic modulation of glutamatergic synaptic transmission in region CA3 of the hippocampus. Eur. J. Neurosci. 22, 1349-1356. doi: 10.1111/j.1460-9568.2005.04316.x

Goutagny, R., Loureiro, M., Jackson, J., Chaumont, J., Williams, S., Isope, P., et al. (2013). Interactions between the lateral habenula and the hippocampus: implication for spatial memory processes. Neuropsychopharmacology 38, 1-9. doi: $10.1038 / \mathrm{npp} .2013 .142$

Gray, R., and Johnston, D. (1987). Noradrenaline and $\beta$-adrenoceptor agonists increase activity of voltage-dependent calcium channels in hippocampal neurons. Nature 327, 620-622. doi: 10.1038/327620a0

Griffith, T., Tsaneva-Atanasova, K., and Mellor, J. R. (2016). Control of Ca2+ influx and calmodulin activation by SK-channels in dendritic spines. PLoS Comput. Biol. 12:e1004949. doi: 10.1371/journal.pcbi.1004949

Grishin, A. A., Benquet, P., and Gerber, U. (2005). Muscarinic receptor stimulation reduces NMDA responses in CA3 hippocampal pyramidal cells via $\mathrm{Ca} 2+-$ dependent activation of tyrosine phosphatase. Neuropharmacology 49, 328337. doi: 10.1016/j.neuropharm.2005.03.019

Grishin, A. A., Gee, C. E., Gerber, U., and Benquet, P. (2004). Differential calciumdependent modulation of NMDA currents in CA1 and CA3 hippocampal pyramidal cells. J. Neurosci. 24, 350-355. doi: 10.1523/JNEUROSCI.493303.2004

Grybko, M., Sharma, G., and Vijayaraghavan, S. (2010). Functional distribution of nicotinic receptors in CA3 region of the hippocampus. J. Mol. Neurosci. 40, 114-120. doi: 10.1007/s12031-009-9266-8

Grybko, M. J., Hahm, E. T., Perrine, W., Parnes, J. A., Chick, W. S., Sharma, G., et al. (2011). A transgenic mouse model reveals fast nicotinic transmission in hippocampal pyramidal neurons. Eur. J. Neurosci. 33, 1786-1798. doi: $10.1111 /$ j.1460-9568.2011.07671.x

Gulyás, A. I., Acsády, L., and Freund, T. F. (1999). Structural basis of the cholinergic and serotonergic modulation of GABAergic neurons in the hippocampus. Neurochem. Int. 34, 359-372. doi: 10.1016/S01970186(99)00041-8

Gundlfinger, A., Breustedt, J., Sullivan, D., and Schmitz, D. (2010). Natural spike trains trigger short- and long-lasting dynamics at hippocampal mossy fiber synapses in rodents. PLoS ONE 5:e9961. doi: 10.1371/journal.pone.0009961

Gundlfinger, A., Leibold, C., Gebert, K., Moisel, M., Schmitz, D., and Kempter, R. (2007). Differential modulation of short-term synaptic dynamics by long-term potentiation at mouse hippocampal mossy fibre synapses. J. Physiol. 585(Pt 3), 853-865. doi: 10.1113/jphysiol.2007.143925
Guo, N. N., and Li, B. M. (2007). Cellular and subcellular distributions of alpha1- and alpha2-Adrenoceptors in the CA1 and CA3 regions of the rat hippocampus. Neuroscience 146, 298-305. doi: 10.1016/j.neuroscience.2007.01.013

Guzman, S. J., Schlögl, A., Frotscher, M., and Jonas, P. (2016). Synaptic mechanisms of pattern completion in the hippocampal ca3 network. Science 353, 1117-1123. doi: 10.1126/science.aaf1836

Haas, H. L., and Konnerth, A. (1983). Histamine and noradrenaline decrease calcium-activated potassium conductance in hippocampal pyramidal cells. Nature 302, 432-434. doi: 10.1038/302432a0

Haas, H. L., and Rose, G. M. (1987). Noradrenaline blocks potassium conductance in rat dentate gyrus cells in vitro. Neurosci. Lett. 78, 171-174. doi: 10.1016/03043940(87)90628-8

Hájos, N., Papp, E. C. S., Acsády, L., Levey, A. I., and Freund, T. F. (1998). Distinct interneuron types express $\mathrm{m} 2$ muscarinic receptor immunoreactivity on their dendrites or axon terminals in the hippocampus. Neuroscience 82, 355-376. doi: 10.1016/S0306-4522(97)00300-X

Hamilton, T. J., Wheatley, B. M., Sinclair, D. B., Bachmann, M., Larkum, M. E., and Colmers, W. F. (2010). Dopamine modulates synaptic plasticity in dendrites of rat and human dentate granule cells. Proc. Natl. Acad. Sci. U.S.A. 107, 18185-18190. doi: 10.1073/pnas.1011558107

Hansen, N., and Manahan-Vaughan, D. (2015a). Hippocampal long-term potentiation that is elicited by perforant path stimulation or that occurs in conjunction with spatial learning is tightly controlled by beta-adrenoreceptors and the locus coeruleus. Hippocampus 25, 1285-1298. doi: 10.1002/hipo.22436

Hansen, N., and Manahan-Vaughan, D. (2015b). Locus coeruleus stimulation facilitates long-term depression in the dentate gyrus that requires activation of $\beta$-adrenergic receptors. Cereb. Cortex 25, 1889-1896. doi: $10.1093 /$ cercor/bht 429

Hasselmo, M. E. (2006). The role of acetylcholine in learning and memory. Curr. Opin. Neurobiol. 16, 710-715. doi: 10.1016/j.conb.2006.09.002

Hasselmo, M. E., Schnell, E., and Barkai, E. (1995). Dynamics of learning and recall at excitatory recurrent synapses and cholinergic modulation in rat hippocampal region CA3. J. Neurosci. 15, 5249-5262.

Hebb, D. O. (1949). The Organization of Behavior. New York, NY: John Wiley \& Sons, Inc.

Hofmann, M. E., and Frazier, C. J. (2010). Muscarinic receptor activation modulates the excitability of hilar mossy cells through the induction of an afterdepolarization. Brain Res. 1318, 42-51. doi: 10.1016/j.brainres.2010.01.011

Hofmann, M. E., Nahir, B., and Frazier, C. J. (2006). Endocannabinoid-mediated depolarization-induced suppression of inhibition in hilar mossy cells of the rat dentate gyrus. J. Neurophysiol. 96, 2501-2512. doi: 10.1152/jn.00310.2006

Hofmann, M. E., Nahir, B., and Frazier, C. J. (2008). Excitatory afferents to CA3 pyramidal cells display differential sensitivity to $\mathrm{CB} 1$ dependent inhibition of synaptic transmission. Neuropharmacology 55, 1140-1146. doi: 10.1016/j.neuropharm.2008.07.007

Hopkins, W. F., and Johnston, D. (1984). Frequency-dependent noradrenergic modulation of long-term potentiation in the hippocampus. Science 226, 350352. doi: $10.1126 /$ science.6091272

Hopkins, W. F., and Johnston, D. (1988). Noradrenergic enhancement of long term potentiation at mossy fiber synapses in the hippocampus. J. Neurophysiol. 59, 667-687.

Hörtnagl, H., Berger, M. L., Sperk, G., and Pifl, C. (1991). Regional heterogeneity in the distribution of neurotransmitter markers in the rat hippocampus. Neuroscience 45, 261-272. doi: 10.1016/0306-4522(91)90224-C

Hu, H., Real, E., Takamiya, K., Kang, M.-G., Ledoux, J., Huganir, R. L., et al. (2007). Emotion enhances learning via norepinephrine regulation of AMPA-receptor trafficking. Cell 131, 160-173. doi: 10.1016/j.cell.2007.09.017

Huang, Y.-Y., and Kandel, E. R. (1996). Modulation of both the early and the late phase of mossy fiber LTP by the activation of $\beta$-adrenergic receptors. Neuron 16, 611-617. doi: 10.1016/S0896-6273(00)80080-X

Hummos, A., Franklin, C. C., and Nair, S. S. (2014). Intrinsic mechanisms stabilize encoding and retrieval circuits differentially in a hippocampal network model. Hippocampus 19, 1-19. doi: 10.1002/hipo.22324

Hunsaker, M. R., Rogers, J. L., and Kesner, R. P. (2007). Behavioral characterization of a transection of dorsal CA3 subcortical efferents: comparison with scopolamine and physostigmine infusions into dorsal CA3. Neurobiol. Learn. Mem. 88, 127-136. doi: 10.1016/j.nlm.2007.01.006 
Hunsaker, M. R., Rosenberg, J. S., and Kesner, R. P. (2008). The role of the dentate gyrus, CA3a,b, and CA3c for detecting spatial and environmental novelty. Hippocampus 18, 1064-1073. doi: 10.1002/hipo.20464

Jacobs, B. L., and Fornal, C. A. (1999). Activity of serotonergic neurons in behaving animals. Neuropsychopharmacology 21(2 Suppl.), 9S-15S. doi: 10.1016/S0893133X(99)00012-3

Jerman, T., Kesner, R. P., and Hunsaker, M. R. (2006). Disconnection analysis of CA3 and DG in mediating encoding but not retrieval in a spatial maze learning task. Learn. Mem. 13, 458-464. doi: 10.1101/lm.246906

Jochems, A., and Yoshida, M. (2013). Persistent firing supported by an intrinsic cellular mechanism in hippocampal CA3 pyramidal cells. Eur. J. Neurosci. 38, 2250-2259. doi: 10.1111/ejn.12236

Jochems, A., and Yoshida, M. (2015). A robust in vivo-like persistent firing supported by a hybrid of intracellular and synaptic mechanisms. PLoS ONE 10, 1-22. doi: 10.1371/journal.pone.0123799

John, D., Shelukhina, I., Yanagawa, Y., Deuchars, J., and Henderson, Z. (2015). Functional $\alpha 7$ nicotinic receptors are expressed on immature granule cells of the postnatal dentate gyrus. Brain Res. 1601, 15-30. doi: 10.1016/j.brainres.2014.12.041

Jones, S. and Yakel, J. L. (1997). Functional nicotinic ACh receptors on interneurones in the rat hippocampus. J. Physiol. 504, 603-610. doi: 10.1111/j.1469-7793.1997.603bd.x

Jung, M. W., and McNaughton, B. L. (1993). Spatial selectivity of unit activity in the hippocampal granular layer. Hippocampus 3, 165-182. doi: 10.1002/hipo.450030209

Jurgens, C. W. D., Rau, K. E., Knudson, C. A., King, J. D., Carr, P. A., Porter, J. E., et al. (2005). $\beta 1$ adrenergic receptor-mediated enhancement of hippocampal CA3 network activity. J. Pharmacol. Exp. Ther. 314, 552-560. doi: 10.1124/jpet.105.085332

Karunakaran, S., Chowdhury, A., Donato, F., Quairiaux, C., Michel, C. M., and Caroni, P. (2016). PV plasticity sustained through D1/5 dopamine signaling required for long-term memory consolidation. Nat. Neurosci. 19, 454-464. doi: 10.1038/nn.4231

Katsuki, H., Izumi, Y., and Zorumski, C. F. (1997). Noradrenergic regulation of synaptic plasticity in the hippocampal CA1 region. J. Neurophysiol. 77, 3013-3020.

Kheirbek, M. A., Drew, L. J., Burghardt, N. S., Costantini, D. O., Tannenholz, L., Ahmari, S. E., et al. (2013). Differential control of learning and anxiety along the dorsoventral axis of the dentate gyrus. Neuron 77, 955-968. doi: 10.1016/j.neuron.2012.12.038

Kitt, C. A., Höhmann, C., Coyle, J. T., and Price, D. L. (1994). Cholinergic innervation of mouse forebrain structures. J. Comp. Neurol. 341, 117-129. doi: 10.1002/cne.903410110

Kobayashi, K., Ikeda, Y., Haneda, E., and Suzuki, H. (2008). Chronic fluoxetine bidirectionally modulates potentiating effects of serotonin on the hippocampal mossy fiber synaptic transmission. J. Neurosci. 28, 6272-6280. doi: 10.1523/JNEUROSCI.1656-08.2008

Kobayashi, K., Ikeda, Y., and Suzuki, H. (2006). Locomotor activity correlates with modifications of hippocampal mossy fibre synaptic transmission. Eur. J. Neurosci. 24, 1867-1873. doi: 10.1111/j.1460-9568.2006.05079.x

Kobayashi, K., and Poo, M. M. (2004). Spike train timing-dependent associative modification of hippocampal CA3 recurrent synapses by mossy fibers. Neuron 41, 445-454. doi: 10.1016/S0896-6273(03)00873-0

Kobayashi, K., and Suzuki, H. (2007). Dopamine selectively potentiates hippocampal mossy fiber to CA3 synaptic transmission. Neuropharmacology 52, 552-561. doi: 10.1016/j.neuropharm.2006.08.026

Kulla, A., and Manahan-Vaughan, D. (2000). Depotentiation in the dentate gyrus of freely moving rats is modulated by D1/D5 dopamine receptors. Cereb. Cortex 10, 614-620. doi: 10.1093/cercor/10.6.614

Kunec, S., Hasselmo, M. E., and Kopell, N. J. (2005). Encoding and retrieval in the CA3 region of the hippocampus: a model of theta-phase separation. J. Neurophysiol. 94, 70-82. doi: 10.1152/jn.00731.2004

Kwon, O. B., Paredes, D., Gonzalez, C. M., Neddens, J., Hernandez, L., Vullhorst, D., et al. (2008). Neuregulin-1 regulates LTP at CA1 hippocampal synapses through activation of dopamine D4 receptors. Proc. Natl. Acad. Sci. U.S.A. 105, 15587-15592. doi: 10.1073/pnas.0805722105

Lacaille, J. C., and Schwartzkroin, P. A. (1988). Intracellular responses of rat hippocampal granule cells in vitro to discrete applications of norepinephrine. Neurosci. Lett. 89, 176-181. doi: 10.1016/0304-3940(88) 90377-1

Lee, I., and Kesner, R. P. (2004). Encoding versus retrieval of spatial memory: Double dissociation between the dentate gyrus and the perforant path inputs into CA3 in the dorsal hippocampus. Hippocampus 14, 66-76. doi: 10.1002/hipo.10167

Lemon, N., and Manahan-Vaughan, D. (2012). Dopamine D1/D5 receptors contribute to de novo hippocampal LTD mediated by novel spatial exploration or locus coeruleus activity. Cereb. Cortex 22, 2131-2138. doi: $10.1093 /$ cercor/bhr297

Lengyel, M., and Dayan, P. (2007). "Uncertainty, phase and oscillatory hippocampal recall," in Advances in Neural Information Processing Systems 19, eds B. Schölkopf, J. C. Platt, and T. Hoffman (MIT Press), 833-840. Available online at: http://papers.nips.cc/paper/3102-uncertainty-phase-andoscillatory-hippocampal-recall

Lengyel, M., Kwag, J., Paulsen, O., and Dayan, P. (2005). Matching storage and recall: hippocampal spike timing-dependent plasticity and phase response curves. Nat. Neurosci. 8, 1677-1683. doi: 10.1038/nn1561

Leranth, C., and Hajszan, T. (2007). Extrinsic afferent systems to the dentate gyrus. Prog. Brain Res. 163, 63-84. doi: 10.1016/S0079-6123(07)63004-0

Leutgeb, J. K., Leutgeb, S., Moser, M.-B., and Moser, E. I. (2007). Pattern separation in the dentate gyrus and CA3 of the hippocampus. Science 315, 961-966. doi: $10.1126 /$ science. 1135801

Levey, A. I., Edmunds, S. M., Koliatsos, V., Wiley, R. G., and Heilman, C. J. (1995). Expression of $\mathrm{m} 1-\mathrm{m} 4$ muscarinic acetylcholine receptor proteins in rat hippocampus and regulation by cholinergic innervation. J. Neurosci. 15(5 Pt 2), 4077-4092.

Li, Q. H., Nakadate, K., Tanaka-Nakadate, S., Nakatsuka, D., Cui, Y., and Watanabe, Y. (2004). Unique expression patterns of 5-HT2A and 5-HT2C receptors in the rat brain during postnatal development: western blot and immunohistochemical analyses. J. Comp. Neurol. 469, 128-140. doi: $10.1002 /$ cne. 11004

Liotta, A., Caliskan, G., ul Haq, R., Hollnagel, J. O., Rosler, A., Heinemann, U., et al. (2011). Partial disinhibition is required for transition of stimulus-induced sharp wave-ripple complexes into recurrent epileptiform discharges in rat hippocampal slices. J. Neurophysiol. 105, 172-187. doi: 10.1152/jn.00186.2010

Lisman, J. E. (1999). Relating hippocampal circuitry to function: recall of memory sequences by reciprocal dentate-CA3 interactions. Neuron 22, 233-242. doi: 10.1016/S0896-6273(00)81085-5

Lisman, J. E., and Otmakhova, N. A. (2001). Storage, recall, and novelty detection of sequences by the hippocampus: elaborating on the SOCRATIC model to account for normal and aberrant effects of dopamine. Hippocampus 11, 551-568. doi: 10.1002/hipo.1071

Losonczy, A., Biró, A. A., and Nusser, Z. (2004). Persistently active cannabinoid receptors mute a subpopulation of hippocampal interneurons. Proc. Natl. Acad. Sci. U.S.A. 101, 1362-1367. doi: 10.1073/pnas.0304752101

Luo, A. H., Tahsili-Fahadan, P., Wise, R. A., Lupica, C. R., and AstonJones, G. (2011). Linking context with reward: a functional circuit from hippocampal CA3 to ventral tegmental area. Science 333, 353-357. doi: $10.1126 /$ science. 1204622

Lüscher, C., Jan, L. Y., Stoffel, M., Malenka, R. C., and Nicoll, R. A. (1997). G protein-coupled inwardly rectifying $\mathrm{K}+$ channels (GIRKs) mediate postsynaptic but not presynaptic transmitter actions in hippocampal neurons. Neuron 19, 687-695. doi: 10.1016/S0896-6273(00)80381-5

Lynch, M. A., and Bliss, T. V. P. (1986). Noradrenaline modulates the release of [14C] glutamate from dentate but not from CA1/CA3 slices of rat hippocampus. Neuropharmacology 25, 493-498. doi: 10.1016/0028-3908(86)90173-5

Maccaferri, G., Tóth, K., and McBain, C. J. (1998). Target-specific expression of presynaptic mossy fiber plasticity. Science 279, 1368-1370. doi: 10.1126/science.279.5355.1368

Madison, D. V., and Nicoll, R. A. (1982). Noradrenaline blocks accommodation of pyramidal cell discharge in the hippocampus. Nature 299, 636-638. doi: $10.1038 / 299636 \mathrm{a} 0$

Madison, D. V., and Nicoll, R. A. (1986). Actions of noradrenaline recorded intracellularly in rat hippocampal CA1 pyramidal neurons, in vitro. J. Physiol. 372, 221-244. doi: 10.1113/jphysiol.1986.sp016006

Maeda, T., Kaneko, S., and Satoh, M. (1994). Inhibitory influence via 5HT3 receptors on the induction of LTP in mossy fiber-CA3 system of 
guinea-pig hippocampal slices. Neurosci. Res. 18, 277-282. doi: 10.1016/01680102(94)90163-5

Manuel-Apolinar, L., Rocha, L., Pascoe, D., Castillo, E., Castillo, C., and Meneses, A. (2005). Modifications of 5-HT4 receptor expression in rat brain during memory consolidation. Brain Res. 1042, 73-81. doi: 10.1016/j.brainres.2005.02.020

Marín-Burgin, A., Mongiat, L., Pardi, M., and Schinder, A. F. (2012). Unique processing during a period of high excitation/inhibition balance in adult-born neurons. Science 335, 1238-1242. doi: 10.1126/science.1214956

Marr, D. (1971). Simple memory: a theory for archicortex. Philos. Trans. R. Soc. Lond. B Biol. Sci. 262, 23-81. doi: 10.1098/rstb.1971.0078

Martinello, K., Huang, Z., Lujan, R., Tran, B., Watanabe, M., Cooper, E. C., et al. (2015). Cholinergic afferent stimulation induces axonal function plasticity in adult hippocampal granule cells. Neuron 85, 346-363. doi: 10.1016/j.neuron.2014.12.030

McHugh, T. J., Jones, M. W., Quinn, J. J., Balthasar, N., Coppari, R., Elmquist, J. K., et al. (2007). Dentate gyrus NMDA receptors mediate rapid pattern separation in the hippocampal network. Science 317, 94-99. doi: 10.1126/science.1140263

McIntyre, C. K., Hatfield, T., and McGaugh, J. L. (2002). Amygdala norepinephrine levels after training predict inhibitory avoidance retention performance in rats. Eur. J. Neurosci. 16, 1223-1226. doi: 10.1046/j.1460-9568.2002.02188.x

McMahon, L. L., and Kauer, J. A. (1997). Hippocampal interneurons are excited via serotonin-gated ion channels. J. Neurophysiol. 78, 2493-2502.

McNaughton, B. L., and Morris, R. G. M. (1987). Hippocampal synaptic enhancement and information storage within a distributed memory system. Trends Neurosci. 10, 408-415. doi: 10.1016/0166-2236(87)90011-7

McQuiston, A. R., and Madison, D. V. (1999). Nicotinic receptor activation excites distinct subtypes of interneurons in the rat hippocampus. J. Neurosci. 19, 2887-2896.

Meeter, M., Murre, J. M. J., and Talamini, L. M. (2004). Mode shifting between storage and recall based on novelty detection in oscillating hippocampal circuits. Hippocampus 14, 722-741. doi: 10.1002/hipo.10214

Meeter, M., Talamini, L., Schmitt, J. A., and Riedel, W. J. (2006). Effects of 5-HT on memory and the hippocampus: model and data. Neuropsychopharmacology 31, 712-720. doi: 10.1038/sj.npp.1300869

Millan, M. J., Marin, P., Bockaert, J., and Mannoury la Cour, C. (2008). Signaling at G-protein-coupled serotonin receptors: recent advances and future research directions. Trends Pharmacol. Sci. 29, 454-464. doi: 10.1016/j.tips.2008.06.007

Milner, T. A., and Bacon, C. E. (1989). GABAergic neurons in the rat hippocampal formation: ultrastructure and synaptic relationships with catecholaminergic terminals. J. Neurosci. 9, 3410-3427.

Milner, T. A., Shah, P., and Pierce, J. P. (2000). $\beta$-Adrenergic receptors primarily are located on the dendrites of granule cells and interneurons but also are found on astrocytes and a few presynaptic profiles in the rat dentate gyrus. Synapse 36, 178-193. doi: 10.1002/(SICI)1098-2396(20000601)36:3<178::AIDSYN3>3.0.CO;2-6

Mishra, R. K., Kim, S., Guzman, S. J., and Jonas, P. (2016). Symmetric spike timingdependent plasticity at CA3-CA3 synapses optimizes storage and recall in autoassociative networks. Nat. Commun. 7:11552. doi: 10.1038/ncomms11552

Missale, C., Nash, S. R., Robinson, S. W., Jaber, M., and Caron, M. G. (1998). Dopamine receptors: from structure to function. Physiol. Rev. 78, 189-225.

Mistry, R., Dennis, S., Frerking, M., and Mellor, J. R. (2011). Dentate gyrus granule cell firing patterns can induce mossy fiber long-term potentiation in vitro. Hippocampus 21, 1157-1168. doi: 10.1002/hipo.20815

Miyawaki, T., Norimoto, H., Ishikawa, T., Watanabe, Y., Matsuki, N., and Ikegaya, Y. (2014). Dopamine receptor activation reorganizes neuronal ensembles during hippocampal sharp waves in vitro. PLoS ONE 9:e104438. doi: 10.1371/journal.pone.0104438

Mlinar, B., Stocca, G., and Corradetti, R. (2015). Endogenous serotonin facilitates hippocampal long-term potentiation at CA3/CA1 synapses. J. Neural Transm. 122, 177-185. doi: 10.1007/s00702-014-1246-7

Mohler, E. G., Shacham, S., Noiman, S., Lezoualc'h, F., Robert, S., Gastineau, M., et al. (2007). VRX-03011, a novel 5-HT4 agonist, enhances memory and hippocampal acetylcholine efflux. Neuropharmacology 53, 563-573. doi: 10.1016/j.neuropharm.2007.06.016

Mori, M., Abegg, M. H., Gähwiler, B. H., and Gerber, U. (2004). A frequencydependent switch from inhibition to excitation in a hippocampal unitary circuit. Nature 431, 453-456. doi: 10.1038/nature02854
Mori, M., Gähwiler, B. H., and Gerber, U. (2007). Recruitment of an inhibitory hippocampal network after bursting in a single granule cell. Proc. Natl. Acad. Sci. U.S.A. 104, 7640-7645. doi: 10.1073/pnas.0702164104

Müller, W., and Connor, J. A. (1991). Dendritic spines as individual neuronal compartments for synaptic $\mathrm{Ca} 2+$ responses. Nature 354, 73-76. doi: $10.1038 / 354073 \mathrm{a} 0$

Nahir, B., Bhatia, C., and Frazier, C. J. (2007). Presynaptic inhibition of excitatory afferents to hilar mossy cells. J. Neurophysiol. 97, 4036-4047. doi: 10.1152/jn.00069.2007

Nakashiba, T. (2008). Transgenic inhibition of synaptic transmission reveals role of CA3 output in hippocampal learning. Science 319, 1260-1264. doi: $10.1126 /$ science. 1151120

Nakashiba, T., Cushman, J. D., Pelkey, K. A., Renaudineau, S., Buhl, D. L., McHugh, T. J., et al. (2012). Young dentate granule cells mediate pattern separation, whereas old granule cells facilitate pattern completion. Cell 149, 188-201. doi: 10.1016/j.cell.2012.01.046

Nakazawa, K., McHugh, T. J., Wilson, M. A., and Tonegawa, S. (2004). NMDA receptors, place cells and hippocampal spatial memory. Nat. Rev. Neurosci. 5, 361-372. doi: 10.1038/nrn1385

Nissen, W., Szabo, A., Somogyi, J., Somogyi, P., and Lamsa, K. P. (2010). Cell type-specific long-term plasticity at glutamatergic synapses onto hippocampal interneurons expressing either parvalbumin or CB1 cannabinoid receptor. J. Neurosci. 30, 1337-1347. doi: 10.1523/JNEUROSCI.3481-09.2010

Nolan, C. R., Wyeth, G., Milford, M., and Wiles, J. (2011). The race to learn: spike timing and STDP can coordinate learning and recall in CA3. Hippocampus 21, 647-660. doi: 10.1002/hipo.20777

Nozaki, K., Kubo, R., and Furukawa, Y. (2016). Serotonin modulates the excitatory synaptic transmission in the dentate granule cells. J. Neurophysiol. 115, 2997-3007. doi: 10.1152/jn.00064.2016

Okuhara, D. Y., and Beck, S. G. (1994). 5-HT1A receptor linked to inwardrectifying potassium current in hippocampal CA3 pyramidal cells. J. Neurophysiol. 71, 2161-2167.

Ondrejcak, T., Wang, Q., Kew, J. N. C., Virley, D. J., Upton, N., Anwyl, R., et al. (2012). Activation of $\alpha 7$ nicotinic acetylcholine receptors persistently enhances hippocampal synaptic transmission and prevents $\mathrm{A} \alpha 7$-mediated inhibition of LTP in the rat hippocampus. Eur. J. Pharmacol. 677, 63-70. doi: 10.1016/j.ejphar.2011.12.008

O'Reilly, R. C., and McClelland, J. L. (1994). Hippocampal conjunctive encoding, storage, and recall: avoiding a trade-off. Hippocampus 4, 661-682.

Parfitt, K. D., Doze, V. A., Madison, D. V., and Browning, M. D. (1992). Isoproterenol increases the phosphorylation of the synapsins and increases synaptic transmission in dentate gyrus, but not in area CA1, of the hippocampus. Hippocampus 2, 59-64. doi: 10.1002/hipo.450020108

Parfitt, K. D., Hoffer, B. J., and Browing, M. D. (1991). Norepinephrine and isoproterenol increase the phosphorylation of synapsin I and synapsin II in dentate slices of young but not aged Fisher 344 rats. Proc. Natl. Acad. Sci. U.S.A. 88, 2361-2365. doi: 10.1073/pnas.88.6.2361

Pazos, A., Cortés, R., and Palacios, J. M. (1985). Quantitative autoradiographic mapping of serotonin receptors in the rat brain. II. Serotonin-2 receptors. Brain Res. 346, 231-249.

Pedarzani, P., and Storm, J. F. (1993). PKA mediates the effects of monoamine transmitters on the $\mathrm{K}+$ current underlying the slow spike frequency adaptation in hippocampal neurons. Neuron 11, 1023-1035. doi: 10.1016/08966273(93)90216-E

Pelkey, K. A., Lavezzari, G., Racca, C., Roche, K. W., and McBain, C. J. (2005). mGluR7 is a metaplastic switch controlling bidirectional plasticity of feedforward inhibition. Neuron 46, 89-102. doi: 10.1016/j.neuron.2005. 02.011

Piguet, P., and Galvan, M. (1994). Transient and long-lasting actions of 5-HT on rat dentate gyrus neurones in vitro. J. Physiol. 481(Pt 3):629-639.

Puighermanal, E., Biever, A., Espallergues, J., Gangarossa, G., De Bundel, D., and Valjent, E. (2015). Drd2-cre: ribotag mouse line unravels the possible diversity of dopamine $\mathrm{d} 2$ receptor-expressing cells of the dorsal mouse hippocampus. Hippocampus 25, 858-875. doi: 10.1002/hipo.22408

Radcliffe, K. A., Fisher, J. L., Gray, R., and Dani, J. A. (1999). Nicotinic modulation of glutamate and GABA synaptic transmission in hippocampal neurons. Ann. N.Y. Acad. Sci. 868, 591-610. doi: 10.1111/j.1749-6632.1999. tb11332.x 
Ramos, B. P., and Arnsten, A. F. T. (2007). Adrenergic pharmacology and cognition: focus on the prefrontal cortex. Pharmacol. Ther. 113, 523-536. doi: 10.1016/j.pharmthera.2006.11.006

Restivo, L., Niibori, Y., Mercaldo, V., Josselyn, S. A., and Frankland, P. W. (2015). Development of adult-generated cell connectivity with excitatory and inhibitory cell populations in the hippocampus. J. Neurosci. 35, 10600-10612. doi: 10.1523/JNEUROSCI.3238-14.2015

Romo-Parra, H., Aceves, J., and Gutiérrez, R. (2005). Tonic modulation of inhibition by dopamine D4 receptors in the rat hippocampus. Hippocampus 15, 254-259. doi: 10.1002/hipo.20049

Rosen, Z. B., Cheung, S., and Siegelbaum, S. A. (2015). Midbrain dopamine neurons bidirectionally regulate CA3-CA1 synaptic drive. Nat. Neurosci. 18, 1-11. doi: 10.1038/nn.4152

Rüdiger, T., and Bolz, J. (2008). Acetylcholine influences growth cone motility and morphology of developing thalamic axons. Cell Adhes. Migr. 2, 30-37. doi: 10.4161/cam.2.1.5909

Ruediger, S., Vittori, C., Bednarek, E., Genoud, C., Strata, P., Sacchetti, B., et al. (2011). Learning-related feedforward inhibitory connectivity growth required for memory precision. Nature 473, 514-518. doi: 10.1038/nature09946

Ruiz, A., Campanac, E., Scott, R. S., Rusakov, D. a., and Kullmann, D. M. (2010). Presynaptic GABAA receptors enhance transmission and LTP induction at hippocampal mossy fiber synapses. Nat. Neurosci. 13, 431-438. doi: $10.1038 /$ nn. 2512

Salin, P. A., Scanziani, M., Malenka, R. C., and Nicoll, R. A. (1996). Distinct shortterm plasticity at two excitatory synapses in the hippocampus. Proc. Natl. Acad. Sci. U.S.A. 93, 13304-13309. doi: 10.1073/pnas.93.23.13304

Sara, S. J. (2009). The locus coeruleus and noradrenergic modulation of cognition. Nat. Rev. Neurosci. 10, 211-223. doi: 10.1038/nrn2573

Saravanan, V., Arabali, D., Jochems, A., Cui, A. X., Gootjes-Dreesbach, L., Cutsuridis, V., et al. (2015). Transition between encoding and consolidation/replay dynamics via cholinergic modulation of CAN current: a modeling study. Hippocampus 25, 1052-1070. doi: 10.1002/hipo.22429

Sariñana, J., Kitamura, T., Künzler, P., Sultzman, L., and Tonegawa, S. (2014). Differential roles of the dopamine 1-class receptors, D1R and D5R, in hippocampal dependent memory. Proc. Natl. Acad. Sci. U.S.A. 111, 8245-8250. doi: 10.1073/pnas. 1407395111

Savin, C., Dayan, P., and Lengyel, M. (2014). Optimal recall from bounded metaplastic synapses: predicting functional adaptations in hippocampal area CA3. PLoS Comput. Biol. 10:e1003489. doi: 10.1371/journal.pcbi.1003489

Scanziani, M., Gahwiler, B. H., and Thompson, S. M. (1993). Presynaptic inhibition of excitatory synaptic transmission mediated by alpha adrenergic receptors in area CA3 of the rat hippocampus in vitro. J. Neurosci. 13, 5393-5401.

Scanziani, M., Gahwiler, B. H., and Thompson, S. M. (1995). Presynaptic inhibition of excitatory synaptic transmission by muscarinic and metabotropic glutamate receptor activation in the hippocampus: are $\mathrm{Ca} 2+$ channels involved? Neuropharmacology 34, 1549-1557.

Scoville, W. B., and Milner, B. (1957). Loss of recent memory after bilateral hippocampal lesions. 1957. J. Neurol. Neurosurg. Psychiatry 20, 11-21. doi: 10.1136/jnnp.20.1.11

Segal, M., Markram, H., and Richter-Levin, G. (1991). Actions of norepinephrine in the rat hippocampus. Prog. Brain Res. 88, 323-330. doi: 10.1016/S00796123(08)63819-4

Sharma, G., Grybko, M., and Vijayaraghavan, S. (2008). Action potentialindependent and nicotinic receptor-mediated concerted release of multiple quanta at hippocampal CA3-mossy fiber synapses. J. Neurosci. 28, 2563-2575. doi: 10.1523/JNEUROSCI.5407-07.2008

Sharma, G., and Vijayaraghavan, S. (2003). Modulation of presynaptic store calcium induces release of glutamate and postsynaptic firing. Neuron 38, 929-939. doi: 10.1016/S0896-6273(03)00322-2

Smith, C. C., and Greene, R. W. (2012). CNS dopamine transmission mediated by noradrenergic innervation. J. Neurosci. 32, 6072-6080. doi: 10.1523/JNEUROSCI.6486-11.2012

Sodickson, D. L., and Bean, B. P. (1996). GABAB receptor-activated inwardly rectifying potassium current in dissociated hippocampal CA3 neurons. J. Neurosci. 16, 6374-6385.

Son, J.-H., and Winzer-Serhan, U. H. (2008). Expression of neuronal nicotinic acetylcholine receptor subunit mRNAs in rat hippocampal GABAergic interneurons. J. Comp. Neurol. 511, 286-299. doi: 10.1002/cne.21828
Squire, L. R. (1992). Memory and the hippocampus: a synthesis from findings with rats, monkeys, and humans. Psychol. Rev. 99, 195-231. doi: 10.1037/0033295X.99.2.195

Straube, T., and Frey, J. U. (2003). Involvement of $\beta$-adrenergic receptors in protein synthesis-dependent late long-term potentiation (LTP) in the dentate gyrus of freely moving rats: the critical role of the LTP induction strength. Neuroscience 119, 473-479. doi: 10.1016/S0306-4522(03)00151-9

Suwa, B., Bock, N., Preusse, S., Rothenberger, A., and Manzke, T. (2014). Distribution of serotonin 4(a) receptors in the juvenile rat brain and spinal cord. J. Chem. Neuroanat. 55, 67-77. doi: 10.1016/j.jchemneu.2013.12.004

Szabadics, J., and Soltesz, I. (2009). Functional specificity of mossy fiber innervation of GABAergic cells in the hippocampus. J. Neurosci. 29, 4239-4251. doi: 10.1523/JNEUROSCI.5390-08.2009

Szabó, G. G., Holderith, N., Gulyás, A. I., Freund, T. F., and Hájos, N. (2010). Distinct synaptic properties of perisomatic inhibitory cell types and their different modulation by cholinergic receptor activation in the CA3 region of the mouse hippocampus. Eur. J. Neurosci. 31, 2234-2246. doi: 10.1111/j.14609568.2010.07292.x

Takeuchi, T., Duszkiewicz, A. J., Sonneborn, A., Spooner, P. A., Yamasaki, M., Watanabe, M., et al. (2016). Locus coeruleus and dopaminergic consolidation of everyday memory. Nature 537, 357-362. doi: 10.1038/nature19325

Tang, A.-H., Karson, M. A., Nagode, D. A., McIntosh, J. M., Uebele, V. N., Renger, J. J., et al. (2011). Nerve terminal nicotinic acetylcholine receptors initiate quantal GABA release from perisomatic interneurons by activating axonal Ttype (Cav3) Ca2 + channels and Ca2+ release from stores. J. Neurosci. 31, 13546-13561. doi: 10.1523/JNEUROSCI.2781-11.2011

Tigaret, C. M., Olivo, V., Sadowski, J. H., Ashby, M. C., and Mellor, J. R. (2016). Coordinated activation of distinct $\mathrm{Ca} 2+$ sources and metabotropic glutamate receptors encodes Hebbian synaptic plasticity. Nat. Commun. 7, 1-15. doi: 10.1038/ncomms10289

Torborg, C. L., Nakashiba, T., Tonegawa, S., and McBain, C. J. (2010). Control of CA3 output by feedforward inhibition despite developmental changes in the excitation-inhibition balance. J. Neurosci. 30, 15628-15637. doi: 10.1523/JNEUROSCI.3099-10.2010

Törk, I. (1990). Anatomy of the serotonergic system. Ann. N.Y. Acad. Sci. 600, 5-9. doi: 10.1111/j.1749-6632.1990.tb16870.x

Toth, K., Suares, G., Lawrence, J. J., Philips-Tansey, E., and McBain, C. J. (2000). Differential mechanisms of transmission at three types of mossy fiber synapse. J. Neurosci. 20, 8279-8289. Available online at: http://www.jneurosci.org/ content/20/22/8279

Treves, A., and Rolls, E. T. (1994). Computational analysis of the role of the hippocampus in memory. Hippocampus 4, 374-391. doi: 10.1002/hipo.450040319

Treviño, M., Vivar, C., and Gutiérrez, R. (2011). Excitation-inhibition balance in the CA3 network-neuronal specificity and activity-dependent plasticity. Eur. J. Neurosci. 33, 1771-1785. doi: 10.1111/j.1460-9568.2011.07670.x

Twarkowski, H., Hagena, H., and Manahan-Vaughan, D. (2016). The 5hydroxytryptamine4 receptor enables differentiation of informational content and encoding in the hippocampus. Hippocampus 26, 875-891. doi: 10.1002/hipo.22569

Tzounopoulos, T., Janz, R., Südhof, T. C., Nicoll, R. A., and Malenka, R. C. (1998). A role for cAMP in long-term depression at hippocampal mossy fiber synapses. Neuron 21, 837-845. doi: 10.1016/S0896-6273(00)80599-1

Ul Haq, R., Anderson, M. L., Hollnagel, J. O., Worschech, F., Sherkheli, M. A., Behrens, C. J., et al. (2016). Serotonin dependent masking of hippocampal sharp wave ripples. Neuropharmacology 101, 188-203. doi: 10.1016/j.neuropharm.2015.09.026

Ul Haq, R., Liotta, A., Kovacs, R., Rosler, A., Jarosch, M. J., Heinemann, U., et al. (2012). Adrenergic modulation of sharp wave-ripple activity in rat hippocampal slices. Hippocampus 22, 516-533. doi: 10.1002/hipo.20918

Vankov, A., Herve-Minvielle, A., and Sara, S. J. (1995). Response to novelty and its rapid habituation in locus coeruleus neurons of the freely exploring rat. Eur. J. Neurosci. 7, 1180-1187. doi: 10.1111/j.1460-9568.1995.tb01108.x

Varga, V., Losonczy, A., Zemelman, B. V., Borhegyi, Z., Nyiri, G., Domonkos, A., et al. (2009). Fast synaptic subcortical control of hippocampal circuits. Science 326, 449-453. doi: 10.1126/science.1178307

Vilaró, M. T., Cortés, R., Gerald, C., Branchek, T. A., Palacios, J. M., and Mengod, G. (1996). Localization of 5-HT4 receptor mRNA in rat brain by in situ 
hybridization histochemistry. Mol. Brain Res. 43, 356-360. doi: 10.1016/S0169328X(96)00248-3

Vilaró, M. T., Cortés, R., and Mengod, G. (2005). Serotonin 5-HT4 receptors and their mRNAs in rat and guinea pig brain: distribution and effects of neurotoxic lesions. J. Comp. Neurol. 484, 418-439. doi: 10.1002/cne.20447

Villani, F., and Johnston, D. (1993). Serotonin inhibits induction of long-term potentiation at commissural synapses in hippocampus. Brain Res. 606, 304-308. doi: 10.1016/0006-8993(93)90998-3

Vogels, T. P., Sprekeler, H., Zenke, F., Clopath, C., and Gerstner, W. (2011). Inhibitory plasticity balances excitation and inhibition in sensory pathways and memory networks. Science 334, 1569-1573. doi: 10.1126/science.1211095

Vogt, K. E., and Regehr, W. G. (2001). Cholinergic modulation of excitatory synaptic transmission in the CA3 area of the hippocampus. J. Neurosci. 21, 75-83. Available online at: http://www.jneurosci.org/content/21/1/75

Walling, S. G., Brown, R. A., Miyasaka, N., Yoshihara, Y., and Harley, C. W. (2012). Selective wheat germ agglutinin (WGA) uptake in the hippocampus from the locus coeruleus of dopamine- $\beta$-hydroxylase-WGA transgenic mice. Front. Behav. Neurosci. 6:23. doi: 10.3389/fnbeh.2012.00023

Walling, S. G., and Harley, C. W. (2004). Locus ceruleus activation initiates delayed synaptic potentiation of perforant path input to the dentate gyrus in awake rats: a novel $\beta$-adrenergic- and protein synthesis-dependent mammalian plasticity mechanism. J. Neurosci. 24, 598-604. doi: 10.1523/JNEUROSCI.4426-03.2004

Wang, J. K. T., Andrews, H., and Thukral, V. (1992). Presynaptic glutamate receptors regulate noradrenaline release from isolated nerve terminals. J. Neurochem. 58, 204-211. doi: 10.1111/j.1471-4159.1992.tb09297.x

Welsby, P. J., Rowan, M., and Anwyl, R. (2006). Nicotinic receptor-mediated enhancement of long-term potentiation involves activation of metabotropic glutamate receptors and ryanodine-sensitive calcium stores in the dentate gyrus. Eur. J. Neurosci. 24, 3109-3118. doi: 10.1111/j.1460-9568.2006.05187.x

Welsby, P. J., Rowan, M. J., and Anwyl, R. (2009). Intracellular mechanisms underlying the nicotinic enhancement of LTP in the rat dentate gyrus. Eur. J. Neurosci. 29, 65-75. doi: 10.1111/j.1460-9568.2008.06562.x

West, M. J., Slomianka, L., and Gundersen, H. J. G. (1991). Unbiased stereological estimation of the total number of neurons in the subdivisions of the rat hippocampus using the optical fractionator. Anat. Rec. 231, 482-497. doi: 10.1002/ar.1092310411

Wiescholleck, V., and Manahan-Vaughan, D. (2014). Antagonism of D1/D5 receptors prevents long-term depression (LTD) and learning-facilitated LTD at the perforant path-dentate gyrus synapse in freely behaving rats. Hippocampus 24, 1615-1622. doi: 10.1002/hipo.22340

Wilke, S. A., Antonios, J. K., Bushong, E. A., Badkoobehi, A., Malek, E., Hwang, M., et al. (2013). Deconstructing complexity: serial block-face electron microscopic analysis of the hippocampal mossy fiber synapse. J. Neurosci. 33, 507-522. doi: 10.1523/JNEUROSCI.1600-12.2013

Williams, S., and Johnston, D. (1988). Muscarinic depression of longterm potentiation in CA3 hippocampal neurons. Science 242, 84-87. doi: $10.1126 /$ science. 2845578

Williams, S., and Johnston, D. (1990). Muscarinic depression of synaptic transmission at the hippocampal mossy fiber synapse. J. Neurophysiol. 64, 1089-1097.

Yang, K., and Dani, J. A. (2014). Dopamine D1 and D5 receptors modulate spike timing-dependent plasticity at medial perforant path to dentate granule cell synapses. J. Neurosci. 34, 15888-15897. doi: 10.1523/JNEUROSCI.240014.2014

Yi, F., Ball, J., Stoll, K. E., Satpute, V. C., Mitchell, S. M., Pauli, J. L., et al. (2014). Direct excitation of parvalbumin-positive interneurons by M1 muscarinic acetylcholine receptors: roles in cellular excitability, inhibitory transmission and cognition. J. Physiol. 592(Pt 16), 3463-3494. doi: 10.1113/jphysiol.2014.275453

Zalutsky, R. A., and Nicoll, R. A. (1990). Comparison of two forms of longterm potentiation in single hippocampal neurons. Science 248, 1619-1624. doi: 10.1126/science.2114039

Zhang, G. and Stackman, R. W. (2015). The role of serotonin 5-HT2A receptors in memory and cognition. Front. Pharmacol. 6:225. doi: 10.3389/fphar.2015. 00225

Conflict of Interest Statement: The authors declare that the research was conducted in the absence of any commercial or financial relationships that could be construed as a potential conflict of interest.

Copyright (c) 2016 Prince, Bacon, Tigaret and Mellor. This is an open-access article distributed under the terms of the Creative Commons Attribution License (CC BY). The use, distribution or reproduction in other forums is permitted, provided the original author(s) or licensor are credited and that the original publication in this journal is cited, in accordance with accepted academic practice. No use, distribution or reproduction is permitted which does not comply with these terms. 